\title{
Financial Knowledge, Confidence, and Sustainable Financial Behavior
}

\author{
David Aristei * and Manuela Gallo
}

check for

updates

Citation: Aristei, D.; Gallo, M. Financial Knowledge, Confidence, and Sustainable Financial Behavior Sustainability 2021, 13, 10926.

https://doi.org/10.3390/su131910926

Academic Editor: Chia-Lin Chang

Received: 23 August 2021

Accepted: 26 September 2021

Published: 30 September 2021

Publisher's Note: MDPI stays neutral with regard to jurisdictional claims in published maps and institutional affiliations.

Copyright: (c) 2021 by the authors. Licensee MDPI, Basel, Switzerland. This article is an open access article distributed under the terms and conditions of the Creative Commons Attribution (CC BY) license (https:// creativecommons.org/licenses/by/ $4.0 /)$.
Department of Economics, University of Perugia, 06123 Perugia, Italy; manuela.gallo@unipg.it

* Correspondence: david.aristei@unipg.it

\begin{abstract}
This paper analyzes the effect of financial knowledge and confidence in shaping individual investment choices, sustainable debt behavior, and preferences for socially and environmentally responsible financial companies. Exploiting data from the "Italian Literacy and Financial Competence Survey" (IACOFI) carried out by the Bank of Italy in early 2020, we address potential endogeneity concerns in order to investigate the causal effect of objective financial knowledge on individual financial behaviors. To this aim, we perform endogenous probit regressions, using the respondent's long-term planning attitude, the use of information and communication technology devices, and the financial knowledge of peers as additional instrumental variables. Our main empirical findings show that objective financial knowledge exerts a positive and significant effect on financial market participation and preferences for ethical financial companies. Moreover, we provide strong empirical evidence about the role of confidence biases on individual financial behaviors. In particular, overconfident individuals display a higher probability of making financial investments, experiencing losses due to investment fraud, and being over-indebted. Conversely, underconfident individuals exhibit suboptimal investment choices, but are less likely to engage in risky financial behaviors.
\end{abstract}

Keywords: financial knowledge; overconfidence; underconfidence; sustainable financial behavior; financial market participation; investment fraud; over-indebtedness; ethical financial companies

\section{Introduction and Motivation}

The literature has provided strong evidence that higher levels of financial knowledge are associated with more sustainable financial behaviors and higher levels of financial health [1-6]. As observed by van Raaij [7], responsible financial behaviors improve personal financial well-being: individuals with responsible financial behavior are less likely to have financial problems, such as over-indebtedness, financial anxiety, and fragility, and to be exposed to investment fraud. Financial behaviors performed in a responsible and sustainable way entail taking controllable and calculated risks, retaining a sufficient part of income for unforeseen expenditures, preventing excessive debt accumulation, engaging in financial planning activities, avoiding impulsive decisions and purchases, and seeking financial advice when one's own competencies are insufficient.

Financial knowledge significantly contributes to improving individuals' economic performance, with beneficial effects on their well-being and, as a consequence, on the wellbeing of the society at large [1]. In fact, people with lower levels of financial knowledge engage in high-cost transactions, incur higher fees and high-cost borrowing [4], and are characterized by greater financial fragility and less ability to manage unexpected financial difficulties [5]. Individuals who are more financially literate are more willing to seek professional financial advice or counselling than people who are less financially literate [8] and are better able to detect financial fraud [9]. Furthermore, they also have high awareness of the potential financial losses or gains derived from suboptimal financial decisions and thus are more willing to seek financial advice [10]. As demonstrated by van Rooij et al. [11], financial literacy could improve wealth accumulation and saving plans, being positively 
related to the likelihood of investing in the stock market. Long-term financial planning capabilities also affect retirement planning behavior, which is associated with better retirement security [12,13]. Lusardi and Tufano [4] also emphasize the significant role of knowledge of the concepts related to debt (i.e., debt literacy) and financial experiences in reducing over-indebtedness.

A further aspect, still scarcely explored in the literature, is the link between financial knowledge and socially responsible investments. Financial literacy and environmental knowledge (i.e., eco-literacy) are generally considered factors that increase preferences for ethical financial companies, which in turn play a key role in promoting sustainable investments [14]. As discussed in Phillips and Johnson [15], a lack of knowledge of the social investment market and inadequate financial literacy represent significant barriers to participation in socially responsible investments. Gutsche and Zwergel [16] point out that basic knowledge and trust in providers of socially responsible investment products are required to overcome at least some of the barriers that limit this kind of investment. Moreover, they find that eco-labelling schemes (especially sustainability certificates) contribute to decreasing information costs for individual investors, encouraging their participation in socially responsible investments. However, Gutsche et al. [17] show that financially literate individuals in Japan, despite being more aware of sustainable investments and having lower participation costs, tend to shun sustainable financial products, possibly to avoid limited risk diversification and restricted investment opportunities related to sustainable investment strategies (e.g., negative screening). In this respect, Rossi et al. [18] also show that individuals who perceive themselves as very knowledgeable in financial matters tend to allocate much lower amounts to socially responsible investments; conversely, individuals who have more objective financial knowledge are significantly more likely to participate in social investments.

Besides objective financial knowledge, self-assessed financial knowledge provides a measure of confidence in one's own financial capabilities and is generally considered an important element for understanding individual financial behavior [10,19]. However, several authors have highlighted that individuals tend to misjudge their skills, incurring cognitive biases. Over- and underestimation of one's actual performance, as well as overand underplacement of one's own performance relative to others, lead to overconfidence and underconfidence biases, respectively [20]. Recent studies have focused on confidence biase in the self-assessment of financial competencies, showing that individuals tend to misjudge their financial skills. The misperception of one's own financial competences and skills may entail negative consequences for financial behavior and decision-making, which affect individual financial well-being in the short- and medium-long term [21]. Specifically, overconfident individuals present a higher likelihood of having carried out some retirement planning, but they do not demonstrate actual retirement preparedness [22]. The condition of overconfidence is associated with various risky behaviors that can have detrimental effects on financial health [23]. A higher self-perception of financial literacy results in a lower propensity to seek financial advice and leads to riskier financial behavior [24-26]. Moreover, overconfident individuals are found to be more likely to experience losses due to investments, or to suffer fraud through unauthorized use of payment cards [27]. Coherently, underconfidence bias leads to investment choices that are not value-maximizing [28] and has a significant negative impact on wealth accumulation and on stock market participation [11,29]. Perceived financial knowledge is relevant for information-searching behavior with regard to socially responsible investments and affects the manner in which consumers make investment decisions [15].

Previous literature has also pointed out the existence of significant gender gaps in financial knowledge and self-confidence. Both financial literacy and confidence matter for financial decision making and, as demonstrated by Bucher-Koenen et al. [30], much of the gender gap in financial knowledge can be attributed to differences in confidence and the remainder to true knowledge differences. Accordingly, Aristei and Gallo [31] provide 
international evidence that women are less likely than men to overestimate their financial skills but tend instead to underestimate their actual financial competencies.

Our work aims at contributing to the literature by providing new insights into the role of financial knowledge and confidence in shaping individual financial behaviors. Using microdata from the "Italian Literacy and Financial Competence Survey" (IACOFI) and addressing potential endogeneity issues, we assess the effects of objective financial knowledge and of confidence biases in the self-assessment of one's own competencies on financial market participation and sustainable financial behaviors. More specifically, following previous literature, we focus on the individual propensity to invest in financial assets, to be exposed to investment fraud, and to engage in unsustainable debt behavior. Furthermore, we assess respondents' preferences for socially and environmentally responsible companies as a proxy for individual attitudes towards sustainable investments.

Based on the above considerations, we posit our first two research hypotheses:

Hypothesis 1 (H1). Financial knowledge exerts a positive effect on financial market participation, contributes to limit hazardous and unsustainable financial behaviors, and increases preferences for socially and environmental responsible financial companies.

Hypothesis 2 (H2). Controlling for the actual level of financial knowledge, confidence biases affect individual financial behaviors and play a crucial role in sustainable debt behaviors.

We further explore the role of misperception of one's own financial competencies on financial behaviors and test the following two additional hypotheses:

Hypothesis 3a (H3a). Overconfident individuals are characterized by higher financial market participation but tend to engage in riskier and less sustainable financial behaviors.

Hypothesis $\mathbf{3 b} \mathbf{( H 3 b ) . ~ U n d e r c o n f i d e n t ~ i n d i v i d u a l s ~ s h o w ~ s u b o p t i m a l ~ i n v e s t m e n t ~ c h o i c e s ~ a n d ~ m o r e ~}$ passive investment patterns but are less likely to make hazardous financial choices.

The remainder of the paper is organized as follows. Section 2 describes the data and the main variables used for the analysis. Section 3 illustrates the econometric methods, while the empirical results are presented and discussed in Section 4. Finally, Section 5 draws conclusions and discusses policy implications.

\section{Data and Measurement}

\subsection{Data}

We use data from the 2020 "Italian Literacy and Financial Competence Survey" (IACOFI), carried out by the Bank of Italy between January and February 2020 on a stratified sample (by gender, age, and area of residence) of approximately 2000 adult individuals between 18 and 79 years old. This survey provides detailed information on respondents' financial knowledge, behavior, and attitudes, based on the harmonized methodology defined by the OECD International Network on Financial Education (OECD/INFE) [32,33], together with their socio-demographic and economic characteristics.

\subsection{Financial Behaviors}

In our empirical analysis, we focus on different dimensions of individual financial behavior that are commonly considered in the literature. First, as in most previous studies $[11,13,19,29,34-37]$, we focus on individual portfolio choices and consider the decision to invest in financial assets. In particular, we define a binary indicator (Financial investment) that equals 1 if the respondent, in the last two years, has invested in stocks and shares, public and private bonds, mutual and pension plans, cryptocurrencies, or initial coin offerings (ICOs). From Table 1, which presents descriptive statistics for all the variables considered in the empirical analysis, we notice that only $9.3 \%$ of the respondents have invested in 
financial products during the last two years, confirming the low levels of financial market participation in Italy [38-40].

Table 1. Descriptive statistics.

\begin{tabular}{lcc}
\hline Variable & Observations & Mean \\
\hline (a) Dependent variables & & \\
Financial investment & 2036 & 0.093 \\
Investment fraud & 2036 & 0.048 \\
Over-indebted & 2036 & 0.081 \\
ESR attitude & 2036 & 0.241 \\
(b) Explanatory variables & & \\
(b1) Financial knowledge and confidence & & \\
Objective FK & 2036 & 3.924 \\
Subjective FK & 1910 & 2.200 \\
Overconfident & 1910 & 0.145 \\
Underconfident & 1910 & 0.303 \\
(b2) Other individual characteristics & & \\
Female & 2036 & 0.518 \\
Age & 2036 & 51.13 \\
Self-employed & 2036 & 0.114 \\
Employee & 2036 & 0.387 \\
Retired & 2036 & 0.272 \\
Budget decision maker & 2036 & 0.441 \\
Married & 2036 & 0.528 \\
Tertiary education & 2036 & 0.198 \\
Upper secondary education & 2036 & 0.425 \\
Household size & 2036 & 2.618 \\
Any young children & 2036 & 0.200 \\
Homeowner with mortgage & 2036 & 0.661 \\
Homeowner without mortgage & 2036 & 0.101 \\
Income: 1060-1549 euro & 2036 & 0.323 \\
Income: 1550-2454 euro & 2036 & 0.311 \\
Income: $>$ 2454 euro & 2036 & 0.240 \\
Risk averse & 2036 & 0.616 \\
\hline Not The & \\
\hline
\end{tabular}

Notes: The table reports average values of all the dependent and explanatory variables, computed using sample weights. Source: Own elaboration on data from the Bank of Italy.

We then account for the respondent's propensity to engage in risky and unsustainable financial behaviors. To this aim, as in Di Salvatore et al. [27], we first define the dummy variable Investment fraud, which is equal to one if the individual accepted advice to invest in a financial product that was later found to be a scam. Furthermore, following Lusardi and Tufano [4] and Kurowski [41], we consider a self-reported measure of over-indebtedness and identify those individuals who declare to have too much debt at the time of the interview as over-indebted (Over-indebted). Table 1 shows that $4.8 \%$ of the respondents have been victims of financial scams, while more than $8 \%$ perceive themselves as excessively indebted.

Finally, we focus on respondents' stated preferences towards ethical financial companies, which provide a proxy for individuals' awareness of socially responsible investments and potential demand for sustainable financial products $[16,18,42]$. We thus define a dichotomous variable (ESR attitude) identifying respondents who report preferring dealing with financial companies that have a strong ethical stance (e.g., investing in renewable energies, excluding investments in businesses perceived to have negative social and environmental effects, etc.). In our sample, about one-quarter of the individuals (24.1\%) report to prefer maintaining relationships with ethical financial companies.

Complete variable definitions are reported in Table A1 in the Appendix A. 


\subsection{Objective and subjective financial knowledge}

As in most empirical studies (see e.g., $[43,44]$ ), we measure individual objective financial knowledge (Objective FK) as the number of correct answers to the seven financial knowledge questions defined by the OECD/INFE harmonized methodology and included in the IACOFI questionnaire. Financial knowledge questions are related to the time value of money, interest paid on a loan, interest plus principal, compound interest, risk and return, inflation, and risk diversification [32,33]. Furthermore, in line with Allgood and Walstad [10] and Pikulina et al. [28], we also consider self-assessed financial knowledge (Subjective FK), measured on an ordinal scale with five possible values: Very low (1), quite low (2), about average (3), quite high (4), and very high (5), as a proxy for the respondent's perception of her/his own financial competencies. As can be noted from Table 1, Italian adults are characterized by average objective and subjective financial knowledge scores equal to 3.92 and 2.12, respectively. Additional descriptive information on objective and subjective financial knowledge (as well as on financial behaviors) disaggregated by individual and household characteristics are presented in Table A2 in the Appendix A.

Once objective and subjective knowledge measures have been defined, in order to assess confidence biases in the self-assessment of one's own financial competencies, we consider the mismatch between actual and self-reported financial knowledge. Specifically, in line with Allgood and Walstad [10] and Xia et al. [29], we define a binary variable (Overconfident) that identifies as overconfident those individuals ranked below the sample mean of the objective financial knowledge score (equal to 3.924), but whose self-reported financial knowledge is above the sample mean (equal to 2.200). Accordingly, the binary indicator Underconfident defines as underconfident those respondents with an objective financial knowledge score higher than the mean, but whose self-reported financial knowledge is lower than the mean. Figure 1 shows the joint and marginal distributions of objective and subjective financial knowledge and highlights the incidence of overconfidence and underconfidence biases. We notice that only $55.2 \%$ of the respondents correctly assess their financial capabilities: less knowledgeable people who correctly recognize their financial illiteracy represent $24.9 \%$ of the sample, while those with higher-than-average levels of both objective and subjective knowledge are $30.3 \%$. Conversely, $44.8 \%$ of the respondents are affected by confidence biases in the self-assessment of their own financial competencies: $14.5 \%$ of the respondents overestimate their financial abilities, while $30.3 \%$ of them understate their actual knowledge.

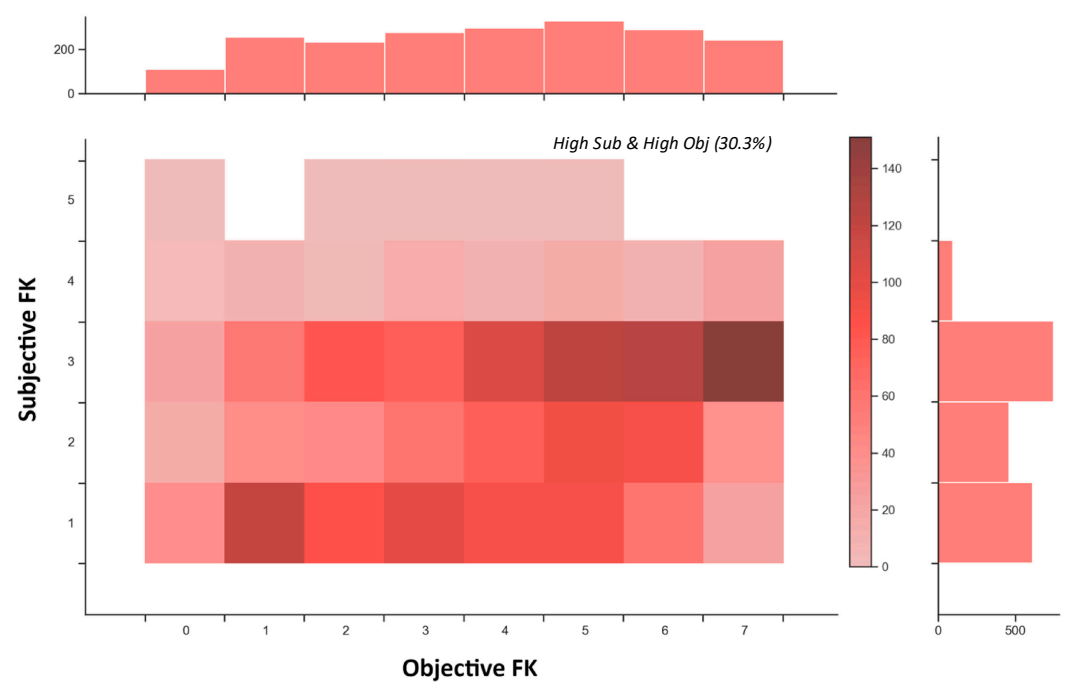

Figure 1. Joint and marginal distributions of objective and subjective financial knowledge. Source: Own elaboration on data from the Bank of Italy.

Table 2 reports the observed proportions and the unconditional differences in the proportions of the financial behavior indicators for the subsamples of individuals with 
objective financial knowledge below and above the average (panel (a)). The proportion of individuals who have invested in financial assets in the last two years is significantly higher, by 5.5 percentage points, in the high financial knowledge group. At the same time, more financially knowledgeable respondents are, on average, 3.0 and 3.5\% less likely to have fallen victim of investment scams and to be over-indebted than individuals in the low knowledge group, respectively. Furthermore, higher levels of knowledge are associated with a greater preference for ethical financial companies: the proportion of individuals declaring to prefer to use financial companies that have a strong ethical stance is $13.7 \%$ higher in the high knowledge group than in the group of less knowledgeable individuals. These results provide preliminary evidence about the crucial role exerted by financial knowledge in shaping individuals' responsible and sustainable financial behavior.

Table 2. Financial behaviors, financial knowledge, and confidence.

(a) Whole sample $(N=2036)$

\begin{tabular}{lccc}
\hline \multicolumn{1}{c}{ Variable } & Objective FK below the mean & Objective FK above the mean & Difference \\
\hline & & & 0.085 \\
Financial investment & 0.030 & 0.030 & $0.055^{* * *}$ \\
Investment fraud & 0.071 & 0.076 & $-0.040^{* * *}$ \\
Over-indebted & 0.111 & 0.299 & $-0.035^{* * *}$ \\
ESR attitude & 0.162 & $0.137^{* * *}$
\end{tabular}

(b) Sub-sample of respondents with a lower-than-average objective $F K(N=780)$

\begin{tabular}{lccc}
\hline \multicolumn{1}{c}{ Variable } & Subjective FK below the mean & $\begin{array}{c}\text { Subjective FK above the mean } \\
\text { (Overconfident) }\end{array}$ & Difference \\
\hline Financial investment & 0.012 & 0.069 & $0.057^{* * *}$ \\
Investment fraud & 0.035 & 0.138 & $0.103^{* * *}$ \\
Over-indebted & 0.081 & 0.171 & $0.090^{* * *}$ \\
$\quad$ ESR attitude & 0.091 & 0.287 & $0.196^{* * *}$ \\
\hline
\end{tabular}

(c) Sub-sample of respondents with a higher-than-average objective FK $(N=1032)$

\begin{tabular}{lcc}
\hline \multicolumn{1}{c}{ Variable } & $\begin{array}{c}\text { Subjective FK below the mean } \\
\text { (Underconfident) }\end{array}$ & Subjective FK above the mean \\
\hline Financial investment & 0.041 & 0.131 \\
Investment fraud & 0.013 & 0.047 \\
Over-indebted & 0.073 & 0.079 \\
ESR attitude & 0.222 & $0.090 * 7^{* * *}$ \\
\end{tabular}

Notes: The table reports average values and (unconditional) differences in the proportions of the outcome variables between the subsamples of individuals with an objective financial knowledge below and above the average value (equal to 3.92) (panel (a)), the subsamples of individuals with a subjective financial knowledge below and above the average value (equal to 2.20), conditional on being below (panel (b)) and above (panel $(c)$ ) the average value of the objective financial knowledge score. ${ }^{* *}, * *$, and ${ }^{*}$ denote the significance of the differences in proportions at 1, 5, and 10\% levels, respectively. Source: Own elaboration on data from the Bank of Italy.

From panel $(b)$ of Table 2, we notice that overconfident individuals who incorrectly self-report higher-than-average knowledge are not only $5.7 \%$ more likely to have invested in financial assets but are also 10.3 and $9 \%$ more likely to have fallen victim to investment scams and to be over-indebted than respondents who properly assess their low financial knowledge, respectively. This evidence highlights the higher financial market participation of overconfident individuals, but also their higher propensity to engage in risky and unsustainable financial behaviors, as documented in Calcagno and Monticone [8], Kramer [26], Xia et al. [29], and Bannier and Neubert [45]. Furthermore, panel (c) of Table 2 shows that underconfident individuals who understate their high financial knowledge are $9 \%$ less likely to invest in financial assets than those who correctly consider themselves as more knowledgeable than the average. At the same time, they are also characterized by a 3.5\% lower vulnerability to investment fraud. This preliminary evidence suggests that 
underconfidence is associated with more passive investment behavior, which may have harmful effects on financial planning and wealth accumulation [11,28], but also with a greater tendency to engage in more sustainable investment decisions.

\subsection{Individual Characteristics}

To properly assess the effects of financial knowledge and confidence biases on individual financial behaviors, and mitigate omitted variable bias as much as possible, we control for a large set of individual socio-demographic characteristics (gender, age (included as a linear and quadratic term), educational attainment, working and marital status, and variables related to the household's composition (size and presence of young children) and economic conditions (net monthly disposable income and homeownership). We also include a dummy identifying risk-averse individuals, as previous studies have highlighted the significant role of risk preferences on individual financial behaviors [11,29,43]. Furthermore, we control for homeownership with and without a mortgage and include a dummy variable indicating whether the individual is responsible for the household's budget; these proxies allow us to partly account for the role of financial and debt experience in affecting financial behaviors and knowledge [4]. Finally, we consider a set of dummies to control for the area of residence and municipality size. Summary statistics for all the explanatory variables considered are reported in Table 1.

\section{Methods}

We first consider a baseline standard probit regression of the binary indicators of individual financial behaviors discussed in Section 2.2 on the number of correct responses to financial knowledge questions (Objective FK), controlling for a large set of other individual observable characteristics. Formally:

$$
Y_{i}=\mathbf{1}\left(\gamma \text { Objective } F K_{i}+\boldsymbol{x}_{i}^{\prime} \boldsymbol{\beta}+\varepsilon_{i}>0\right)
$$

where $\mathbf{1}(\cdot)$ is an indicator function (equal to 1 if the expression in parentheses is true and 0 otherwise), $Y_{i}$ represents different financial behaviors (i.e., Financial investment, Investment fraud, Over-indebted, ESR attitude), $x_{i}$ is a vector of covariates, $\beta$ is the corresponding parameter vector, and errors $\varepsilon_{i}$ are assumed to follow a standard normal distribution.

Previous literature $[43,44,46]$ has emphasized that an individual's objective financial knowledge may be endogenously determined with respect to her/his financial behavior. Endogeneity of financial knowledge may be due to an omitted variable bias stemming from the existence of unobservable factors that simultaneously influence individual financial behaviors and financial knowledge [26,47]. At the same time, endogeneity may be due to a reverse causation channel, as financial knowledge may be affected by the experience gained from previous financial decisions and by individuals' efforts to improve their own financial competencies to better manage their investments $[13,48,49]$. Furthermore, testbased measures of financial knowledge may not allow to properly measure "true" financial knowledge, and this measurement error may give rise to an endogeneity issue, possibly leading to downwardly biased estimates of the impact of financial knowledge [11,12]. All these potential endogeneity concerns should be properly taken into account to allow for a causal interpretation of the effect of financial knowledge on financial behavior. Following Klapper et al. [2] and Fornero and Monticone [13], we extend the standard (exogenous) probit model in Equation (1) to account for the potential endogeneity of financial knowledge. To this aim, we consider a probit model with one endogenous continuous regressor, which can be formalized as the following two-equation recursive system:

$$
\left\{\begin{array}{l}
Y_{i}=1\left(\gamma \text { Objective } F K_{i}+\boldsymbol{x}_{i}^{\prime} \boldsymbol{\beta}_{\mathbf{1}}+\varepsilon_{i}>0\right) \\
\text { Objective } F K_{i}=\boldsymbol{x}_{i}^{\prime} \boldsymbol{\beta}_{\mathbf{2}}+\boldsymbol{z}_{i}^{\prime} \boldsymbol{\alpha}+u_{i}
\end{array}\right.
$$

where the second equation defines a reduced-form equation for Objective FK (i.e., the number of correct answers to financial knowledge questions) as a linear function of the 
exogenous individual-level covariates in $x_{i}$ and a set of additional instrumental variables $z_{i}$, assumed to directly affect an individual's financial knowledge (i.e., relevant) but not to directly impact individual financial behaviors (i.e., exogenous). The error terms $\varepsilon_{i}$ and $u_{i}$ in model (2) are assumed to follow a bivariate normal distribution with zero means, variances respectively equal to 1 and $\sigma_{u}^{2}$, and arbitrary correlation $\rho \sigma_{u}$ (i.e., $\left.\left(\varepsilon_{i}, u_{i}\right) \sim B V N\left[(0,0) ;\left(1, \sigma_{u}^{2}\right) ; \rho \sigma_{u}\right]\right)$. Endogeneity of financial knowledge arises from the error correlation: when $\rho \neq 0$, then Objective $F K_{i}$ and $\varepsilon_{i}$ are correlated and a standard probit of $Y$ on Objective $F K_{i}$ and $x_{i}$ will lead to inconsistent estimates of the $\gamma$ and $\beta$ parameters.

Following Pikulina et al. [28] and Xia et al. [29], we further extend the baseline model to take into account the role of confidence in one's own financial competencies. Specifically, controlling for objective financial knowledge and other individual observable characteristics, we aim to assess the impact of overconfidence and underconfidence biases on individual financial behaviors. In our empirical analysis, we thus extend model (1) and consider the following extended standard probit specification:

$$
Y_{i}=1\left(\gamma \text { Objective } F K_{i}+\text { SOverconfident }+\theta \text { Underconfident }+\boldsymbol{x}_{i}^{\prime} \boldsymbol{\beta}+\varepsilon_{i}>0\right)
$$

which includes the binary indicators Overconfident and Underconfident as additional regressors. Further, in this case, differently from previous studies [28,29], we explicitly allow Objective $F K$ to be endogenously determined with respect to financial behaviors and specify the following bivariate recursive system:

$$
\left\{\begin{array}{l}
Y_{i}=1\left(\gamma \text { Objective } F K_{i}+\delta_{1} \text { Overconfident }+\theta_{1} \text { Underconfident }+\boldsymbol{x}_{i}^{\prime} \boldsymbol{\beta}_{\mathbf{1}}+\varepsilon_{i}>0\right) \\
\text { Objective } F K_{i}=\delta_{2} \text { Overconfident }+\theta_{2} \text { Underconfident }+\boldsymbol{x}_{i}^{\prime} \boldsymbol{\beta}_{\mathbf{2}}+\boldsymbol{z}_{i}^{\prime} \boldsymbol{\alpha}+u_{i}
\end{array} .\right.
$$

where cross-equation error correlation $\rho$ allows us to directly assess the endogeneity of financial knowledge with respect to individual financial behaviors.

In the next Section, we present and discuss results obtained from maximum likelihood (ML) estimation of the standard and endogenous probit models for the four binary indicators of individual financial behavior and compute average marginal effects to properly gauge the magnitude of the effects of objective financial knowledge and confidence indicators, while controlling for individual-level socio-demographic characteristics.

\section{Results and Discussion}

\subsection{Financial Market Participation}

Table 3 reports average marginal effects of the regressors, estimated from both standard and endogenous probit models for the probability of having invested in financial assets during the last two years.

We first consider an empirical specification (model (a)) that focuses on the role of objective financial knowledge on financial behavior. Focusing on standard probit results (column 1 of Table 3), we notice that objective financial knowledge exerts a positive and statistically significant (at the 1\% level) effect on financial market participation. In particular, an additional correct answer to the financial literacy questions increases the probability of investing in financial assets by about one percentage point. Moreover, the investment decision is positively and significantly associated with having a high disposable income and a high education level, being married, and owning a home (with a mortgage). Working status also exerts a significant effect, with self-employed, employed, and retired individuals having a significantly higher investment probability than those unemployed or not in the labor force. Conversely, household size and risk aversion significantly reduce the investment probability, while a respondent's gender and age have no effect. 
Table 3. The determinants of financial investment: Average marginal effects.

\begin{tabular}{|c|c|c|c|c|c|c|}
\hline & \multicolumn{3}{|c|}{ Model (a) } & \multicolumn{3}{|c|}{ Model (b) } \\
\hline & \multirow{2}{*}{$\begin{array}{c}\text { Probit } \\
(1)\end{array}$} & \multicolumn{2}{|c|}{ Endogenous Probit } & \multirow{2}{*}{$\begin{array}{c}\text { Probit } \\
(4)\end{array}$} & \multicolumn{2}{|c|}{ Endogenous Probit } \\
\hline & & (2) & (3) & & (5) & (6) \\
\hline & $\begin{array}{c}\text { Financial } \\
\text { Investment }\end{array}$ & $\begin{array}{c}\text { Financial } \\
\text { Investment }\end{array}$ & $\begin{array}{l}\text { Objective } \\
\text { FK }\end{array}$ & $\begin{array}{c}\text { Financial } \\
\text { Investment }\end{array}$ & $\begin{array}{c}\text { Financial } \\
\text { Investment }\end{array}$ & $\begin{array}{c}\text { Objective } \\
\text { FK }\end{array}$ \\
\hline Objective FK & $\begin{array}{c}0.0092^{* * *} \\
(0.0025)\end{array}$ & $\begin{array}{c}0.1154^{* * *} \\
(0.0148)\end{array}$ & & $\begin{array}{c}0.0129 * * * \\
(0.0027)\end{array}$ & $\begin{array}{c}0.0885^{* * *} \\
(0.0167)\end{array}$ & \\
\hline Overconfident & & & & 0.0200 & $0.1628^{* * *}$ & $-\underset{* * *}{1.8903}$ \\
\hline Underconfident & & & & $\begin{array}{c}(0.0223) \\
-0.0247 * \\
(0.0142)\end{array}$ & $\begin{array}{c}(0.0347) \\
-0.1364^{* * *} \\
(0.0347)\end{array}$ & $\begin{array}{c}(0.1828) \\
1.5623^{* * *} \\
(0.1318)\end{array}$ \\
\hline Female & -0.0083 & 0.0209 & $\underset{* *}{-0.2353}$ & -0.0085 & 0.0116 & -0.2433 \\
\hline Age & $\begin{array}{c}(0.0087) \\
-0.0001 \\
(0.0005)\end{array}$ & $\begin{array}{c}(0.0193) \\
0.0006 \\
(0.0009)\end{array}$ & $\begin{array}{c}(0.1159) \\
-0.0044 \\
(0.0047)\end{array}$ & $\begin{array}{c}(0.0090) \\
-0.0001 \\
(0.0006)\end{array}$ & $\begin{array}{c}(0.0149) \\
0.0001 \\
(0.0008)\end{array}$ & $\begin{array}{c}(0.0860) \\
0.0006 \\
(0.0034)\end{array}$ \\
\hline Self employed & $\begin{array}{c}0.0600^{* * *} \\
(0.0206)\end{array}$ & $\begin{array}{c}0.0426 \\
(0.0328)\end{array}$ & $\begin{array}{c}0.1311 \\
(0.1795)\end{array}$ & $\begin{array}{c}0.0580^{* * *} \\
(0.0212)\end{array}$ & $\begin{array}{c}0.0427 \\
(0.0317)\end{array}$ & $\begin{array}{c}0.2576 \\
(0.2073)\end{array}$ \\
\hline Employee & $\begin{array}{c}0.0542 * * * \\
(0.0156)\end{array}$ & $\begin{array}{c}0.0724^{* * * *} \\
(0.0262)\end{array}$ & $\begin{array}{c}-0.1446 \\
(0.1601)\end{array}$ & $\begin{array}{c}0.0556^{* * *} \\
(0.0162)\end{array}$ & $\begin{array}{c}0.0649 * * * \\
(0.0229)\end{array}$ & $\begin{array}{c}0.0088 \\
(0.1604)\end{array}$ \\
\hline Retired & $\begin{array}{c}0.0554^{* *} \\
(0.0227)\end{array}$ & $\begin{array}{c}0.0620 \\
(0.0393)\end{array}$ & $\begin{array}{l}-0.0149 \\
(0.1606)\end{array}$ & $\begin{array}{l}0.0527^{*} \\
(0.0287)\end{array}$ & $\begin{array}{c}0.0611 \\
(0.0396)\end{array}$ & $\begin{array}{c}0.0457 \\
(0.1388)\end{array}$ \\
\hline Budget decision maker & $\begin{array}{c}0.0418^{* * *} \\
(0.0141)\end{array}$ & $\begin{array}{c}-0.0355 \\
(0.0232)\end{array}$ & $\begin{array}{c}0.6588^{* * *} \\
(0.1249)\end{array}$ & $\begin{array}{c}0.0396^{* *} \\
(0.0155)\end{array}$ & $\begin{array}{l}-0.0047 \\
(0.0154)\end{array}$ & $\begin{array}{c}0.5831^{* * *} \\
(0.0885)\end{array}$ \\
\hline Married & $\begin{array}{c}0.0395^{* * *} \\
(0.0141)\end{array}$ & $\begin{array}{c}0.0556^{* *} \\
(0.0216)\end{array}$ & $\begin{array}{l}-0.1184 \\
(0.1186)\end{array}$ & $\begin{array}{c}0.0447^{* * *} \\
(0.0143)\end{array}$ & $\begin{array}{c}0.0558^{* * *} \\
(0.0181)\end{array}$ & $\begin{array}{l}-0.0163 \\
(0.0839)\end{array}$ \\
\hline Tertiary education & $\begin{array}{c}0.0527^{* * *} \\
(0.0195)\end{array}$ & $\begin{array}{c}-0.0125 \\
(0.0351)\end{array}$ & $\begin{array}{c}0.6240 * * * \\
(0.1552)\end{array}$ & $\begin{array}{c}0.0508 \text { ** } \\
(0.0234)\end{array}$ & $\begin{array}{l}-0.0085 \\
(0.0331)\end{array}$ & $\begin{array}{c}0.9276^{* * *} \\
(0.1528)\end{array}$ \\
\hline Upper secondary education & $\begin{array}{c}0.0221 \\
(0.0150)\end{array}$ & $\begin{array}{l}-0.0279 \\
(0.0274)\end{array}$ & $\begin{array}{c}0.4461^{* * *} \\
(0.1450)\end{array}$ & $\begin{array}{c}0.0215 \\
(0.0176)\end{array}$ & $\begin{array}{l}-0.0211 \\
(0.0278)\end{array}$ & $\begin{array}{c}0.5859 * * * \\
(0.1336)\end{array}$ \\
\hline Household size & $\begin{array}{c}-0.0250^{* * *} \\
(0.0045)\end{array}$ & $\begin{array}{c}-0.0307^{* * *} \\
(0.0114)\end{array}$ & $\begin{array}{c}0.0111 \\
(0.0700)\end{array}$ & $\begin{array}{c}-0.0279^{* * *} \\
(0.0056)\end{array}$ & $\begin{array}{c}-0.0357^{* * *} \\
(0.0096)\end{array}$ & $\begin{array}{c}-0.0144 \\
(0.0617)\end{array}$ \\
\hline Any young children & $\begin{array}{c}0.0057 \\
(0.0187)\end{array}$ & $\begin{array}{c}0.0059 \\
(0.0248)\end{array}$ & $\begin{array}{c}0.0341 \\
(0.1055)\end{array}$ & $\begin{array}{c}0.0091 \\
(0.0195)\end{array}$ & $\begin{array}{c}0.0171 \\
(0.0261)\end{array}$ & $\begin{array}{l}-0.0215 \\
(0.0960)\end{array}$ \\
\hline Homeowner with mortgage & $\begin{array}{c}0.0397^{* * * *} \\
(0.0124)\end{array}$ & $\begin{array}{l}0.0521^{*} \\
(0.0304)\end{array}$ & $\begin{array}{l}-0.1009 \\
(0.2045)\end{array}$ & $\begin{array}{c}0.0399 * * * \\
(0.0128)\end{array}$ & $\begin{array}{l}0.0409^{*} \\
(0.0236)\end{array}$ & $\begin{array}{c}0.0753 \\
(0.1752)\end{array}$ \\
\hline Homeowner without mortgage & 0.0351 & $0.0931^{* * *}$ & $-\underset{* * *}{-0.5616}$ & 0.0350 & 0.0538 * & -0.2280 \\
\hline Income: 1060-1549 euro & $\begin{array}{c}(0.0216) \\
0.0124 \\
(0.0152)\end{array}$ & $\begin{array}{c}(0.0332) \\
-0.0454 \\
(0.0381)\end{array}$ & $\begin{array}{c}(0.1860) \\
0.5572^{* * *} \\
(0.1644)\end{array}$ & $\begin{array}{c}(0.0221) \\
0.0146 \\
(0.0165)\end{array}$ & $\begin{array}{c}(0.0285) \\
-0.0025 \\
(0.0370)\end{array}$ & $\begin{array}{c}(0.1608) \\
0.2861^{* *} \\
(0.1443)\end{array}$ \\
\hline Income: $1550-2454$ euro & $\begin{array}{c}0.0252 \\
(0.0161)\end{array}$ & $\begin{array}{c}-0.0985 \text { ** } \\
(0.0422)\end{array}$ & $\begin{array}{c}1.2251 \text { *** } \\
(0.1814)\end{array}$ & $\begin{array}{c}0.0280 \\
(0.0174)\end{array}$ & $\begin{array}{l}-0.0251 \\
(0.0343)\end{array}$ & $\begin{array}{c}0.8547^{* * *} \\
(0.1476)\end{array}$ \\
\hline Income: $>2454$ euro & $\begin{array}{c}0.0535^{* * * *} \\
(0.0187)\end{array}$ & $\begin{array}{l}-0.0857 \\
(0.0583)\end{array}$ & $\begin{array}{c}1.3318^{* * * *} \\
(0.2592)\end{array}$ & $\begin{array}{c}0.0563 \text { *** } \\
(0.0195)\end{array}$ & $\begin{array}{c}0.0011 \\
(0.0440)\end{array}$ & $\begin{array}{c}0.8844^{* * *} \\
(0.2057)\end{array}$ \\
\hline Risk averse & $\begin{array}{c}-0.0431 * * * \\
(0.0100)\end{array}$ & $\begin{array}{c}-0.1015^{* * *} \\
(0.0172)\end{array}$ & $\begin{array}{c}0.5406^{* * *} \\
(0.0898)\end{array}$ & $\begin{array}{c}-0.0407^{* * *} \\
(0.0097)\end{array}$ & $\begin{array}{c}-0.0526^{* * *} \\
(0.0170)\end{array}$ & $\begin{array}{c}0.0787 \\
(0.0997)\end{array}$ \\
\hline Peer-group objective FK & & & $\begin{array}{c}0.1211 \\
(0.0932)\end{array}$ & & & $\begin{array}{c}0.2114 * * \\
(0.0857)\end{array}$ \\
\hline Long-term attitude & & & $\begin{array}{c}0.3761^{* * *} \\
(0.0914)\end{array}$ & & & $\begin{array}{c}0.6192^{* * *} \\
(0.0946)\end{array}$ \\
\hline ICT use & & & $\begin{array}{c}0.4493 * * \\
(0.1816)\end{array}$ & & & $\begin{array}{c}0.6147^{* * *} \\
(0.1945)\end{array}$ \\
\hline Exogeneity test $(\rho=0)$ & & {$[0.00$} & & & {$[0.00$} & \\
\hline ALN overidentification test & & {$[0.17$} & & & {$[0.17$} & \\
\hline Weak-instrument $F$ test & & {$[0.00$} & & & {$[0.00$} & \\
\hline $\mathrm{N}$ & 2036 & 20 & & 1910 & 19 & \\
\hline Log Likelihood & -354.62 & -453 & & -343.11 & -389 & \\
\hline
\end{tabular}

Notes: The table reports the average marginal effects on the probability of having invested in financial assets in the last two years, estimated from standard and endogenous probit models. Estimated average marginal effects on the number of correct answers to financial knowledge questions are also reported in columns (3) and (6). All the regressions include macro area and municipality size dummies. Robust standard errors, clustered by macro area and age class, are reported in parentheses below the estimates. The $p$-values of the exogeneity test, the Amemiya-Lee-Newey overidentification test, and the $F$ test for weak instruments are reported in square brackets. ${ }^{* * *},{ }^{* *}$, and ${ }^{*}$ denote significance at 1,5, and 10\% levels, respectively. Source: Own elaboration on data from the Bank of Italy. 
As discussed in Section 3, financial knowledge may be endogenous with respect to individual financial behavior, due to omitted-variable bias, reverse causality, and measurement errors, leading to biased parameter estimates. For this reason, we explicitly allow for the possibility that financial knowledge is endogenously determined and extend the standard probit approach by jointly modelling financial market participation and objective financial knowledge by means of a bivariate system of equations. Columns 2 and 3 of Table 3 report the average marginal effects on financial investment probability and on the number of correct responses to financial knowledge questions, respectively. Before commenting on the estimated effects, we discuss the identification strategy and formally test the exogeneity of financial knowledge.

Despite the difficulties in finding valid instruments for financial knowledge [13,43,50], in all the endogenous probit models we consider two types of instrumental variables related to the knowledge of the respondent's reference group and to her/his financial attitudes. The first instrumental variable (Peer-group objective FK) hinges on the idea that an individual's financial knowledge is influenced by the financial knowledge of her/his peer or reference group $[2,11,48,51]$, defined as those individuals living in the same macro-area and belonging to the same age class of the respondent. The assumption behind the choice of this instrument is that the there is no "reflection problem" [52], that is the respondent cannot significantly affect the behavior of the peer. In particular, following Bucher-Koenen and Lusardi [49], we assume that individuals exposed to financially knowledgeable people become more knowledgeable themselves and that the financial knowledge of the group is beyond the control of the individual. The second set of instruments relates to the respondent's tendency to plan for the long-term (Long-term attitude) and to use information and communications technology (ICT) instruments (i.e., banking apps or money management tools on a computer, mobile phone, and/or tablet) to keep note of payment deadlines and track income and expenses (ICT use). As in Fornero and Monticone [13] and French et al. [53], the assumption is that these factors contribute to directly affecting the incentive to increase financial competencies, but they only indirectly affect financial choices through the financial knowledge channel. To assess the validity of our identification strategy, we first test the exogeneity of the additional instrumental variables by means of the Amemiya-Lee-Newey overidentification test. Results clearly indicate that the additional instruments considered are exogenous ( $p$-value equal to 0.1792). Furthermore, results of the $F$ test for the joint significance of the instrumental variables in the reduced-form equation of financial knowledge allow us to reject the null hypothesis that the instruments are weak at the $1 \%$ level ( $p$-value equal to 0.0002$)$. After having provided support for the instruments' validity, we assess the endogeneity of financial knowledge by means of a significance test of the cross-equation error correlation $\rho$. Results of this formal exogeneity test indicate that financial knowledge cannot be considered as exogenously determined with respect to investment choices ( $p$-value equal to 0.0000 ). The endogenous probit model should thus be preferred against the standard probit, as it allows us to address the endogeneity of financial knowledge and obtain consistent parameter estimates. To further assess the appropriateness of our identification strategy and the robustness of our empirical findings, we also use linear probability models estimated using both two-stage least squares and the generated instruments method proposed by Lewbel [54]. Results of these analyses, not reported here but available upon request, confirm the validity of our identification strategy and provide estimates of the effects of financial knowledge that are in line with those obtained from endogenous probit regressions.

Column 2 of Table 3 reports the average marginal effects of the covariates on the probability of investing in financial assets estimated from the endogenous probit model. The estimated impact of financial knowledge remains positive and statistically significant at the $1 \%$ level, but the magnitude of the effect strongly increases. Specifically, when endogeneity is properly taken into account, a unit increase in the number of correct answers to financial knowledge questions raises the likelihood of participating in financial markets by about 11.5 percentage points. In this application, the marginal effect estimated by means 
of the endogenous probit is thus more than 11 times larger than that estimated from the standard probit. This evidence provides support for the significant downward bias in the estimation of the impact of financial knowledge that arises when its endogenous nature is not modelled, as already pointed out in most previous empirical studies [13,46,50].

With respect to the effect of the other control variables, most of the results obtained in the standard probit remain confirmed. In particular, respondents who are married, employed, and homeowners (with and without a mortgage) are characterized by a higher probability to invest in financial assets, while financial market participation decreases with risk aversion and household size. Conversely, when the endogeneity of the financial knowledge is taken into account, income and education levels do not exert a significant impact on individual financial investment behavior.

Finally, estimated marginal effects obtained from the reduced-form equation for Objective FK (column 3 of Table 3) allows for assessing the main determinants of objective financial knowledge. Coherently with the findings of Bucher-Koenen et al. [30,55], Cupák et al. [56], Swiecka et al. [57], Kadoya and Khan [58], and Aristei and Gallo [59], we provide evidence of a significant gender gap in objective financial knowledge: all other things being equal, women are characterized by a number of correct answers 0.235 lower than that of men. Moreover, individuals who are responsible for the household's budget, have higher education levels and higher disposable income, and more risk averse have significantly higher objective financial knowledge, supporting the significant role of financial experience, educational attainment, and income levels in increasing financial competencies [4].

We further extend the baseline specification to account for the effect of confidence in one's own financial competencies on financial behavior. To this aim, we include the dummies Overconfident and Underconfident as additional regressors in the probit regressions (model (b)), considering as the omitted reference group those individuals who correctly assess their financial knowledge (i.e., those with high subjective and high objective knowledge and those with low subjective and low objective knowledge). It is worth remarking that, due to the 126 missing values related to subjective financial knowledge, the estimation sample is reduced to 1910 observations. Results reported in column 4 of Table 3 largely confirm the evidence obtained in the baseline standard probit. In particular, an additional correct answer to the financial knowledge questions significantly increases the probability of financial market participation by about $1.3 \%$ percentage points. At the same time, overconfidence bias does not affect investment behavior, while underconfident individuals are $2.47 \%$ less likely to invest in financial assets than those correctly assessing their financial knowledge. Furthermore, in this case, we allow for the potential endogeneity of objective knowledge by specifying an endogenous probit model, using the same identification strategy discussed above. Results reported in columns 5 and 6 of Table 3 support the validity of the additional instruments considered and confirm that financial knowledge is endogenously determined with individual investment choices. Focusing on the estimated marginal effects, a unit increase in the number of correct responses significantly raises investment probability by about 8.9 percentage points. Coherently with the evidence obtained in the baseline specification, this result confirms that the standard probit produces severely downwardly biased estimates of the impact of financial knowledge and further highlights the necessity of accounting for the endogeneity of objective knowledge with respect to individual financial behaviors. Furthermore, we provide strong empirical evidence about the role of confidence biases in affecting investment choices. In line with the results of Allgood and Walstad [10], Pikulina et al. [28], and Xia et al. [29], we find that individuals overestimating their actual financial knowledge are $16.28 \%$ more likely to invest in financial assets than similar individuals who correctly assess their competencies; at the same time, underconfident individuals have a participation probability about $13.6 \%$ lower than the reference group. Thus, taking into account the endogeneity of actual financial knowledge and controlling for other socio-demographic characteristics, we show that overconfidence bias leads to excess entry into financial markets, while underconfidence 
bias makes individuals more likely to refrain from investing in financial assets. Overall, the evidence obtained suggests that overconfident individuals tend to engage in excess trading, whereas underconfident individuals inappropriately choose passive investment patterns; both of these investment behaviors may have negative consequences on financial planning and wealth accumulation [11,28].

\subsection{Vulnerability to Investment Fraud}

After having assessed the determinants of financial investment, we focus on financial investment behavior and analyze the role of financial knowledge and confidence on individual vulnerability to investment fraud. To this aim, we estimate standard and endogenous probit models for the probability of having invested in a financial product that later proved to be a scam, adopting the same empirical approach used in the analysis of financial market participation. Results reported in Table 4 show that financial knowledge is also endogenously determined with respect to hazardous investment choices: for both the baseline and extended specifications, exogeneity of financial knowledge is rejected at the $5 \%$ level and results of the instrument validity tests support the appropriateness of our identification strategy. Based on this evidence, in discussing estimation results, we mainly focus on the average marginal effects estimated from the endogenous probit. In particular, from column 2 of Table 4 we find that objective financial knowledge, despite having the expected sign, has no significant effect on the probability of being a victim of financial fraud. This evidence is in line with the findings of DeLiema et al. [60] who show that more financially literate and educated adults are not immune to investment fraud. At the same time, the determinants of the probability of having experienced an investment fraud are similar to those of financial market participation, suggesting that individuals who are more likely to invest in financial assets are also more exposed to financial scams, as they are more likely to be targeted by fraudsters [7].

Focusing on the extended specification (model (b)), we find that financial knowledge remains statistically insignificant, whereas confidence biases in assessing one's own financial competencies emerge as significant determinants of individual susceptibility to investment fraud. Specifically, we find that respondents who overestimate their financial knowledge are about 6\% more likely to have experienced fraud than those correctly assessing their capabilities. At the same time, individuals who understate their financial competencies are $4.9 \%$ less likely to experience financial scams than the reference group. Thus, misperception of one's own financial abilities rather than actual knowledge seems to determine individual propensity to engage in hazardous financial behaviors. This evidence is in line with the findings of Di Salvatore et al. [27] and clearly points out the detrimental role of financial knowledge overconfidence on financial decision-making. As discussed in van Raaij [7] and Deevy et al. [61], individuals who are excessively confident in their actual financial capabilities are more prone to underestimate actual investment risks and this makes them particularly vulnerable to financial scams and investment fraud.

\subsection{Sustainable Debt Behavior and Over-Indebtedness}

Table 5 reports results the determinants of the probability of being excessively indebted. As in the previous analyses, we find that the endogenous probit model is necessary to take into account the endogeneity of objective financial knowledge and avoid biased estimates; moreover, results of overidentification and weak-instrument tests confirm, once again, the validity of our identification strategy. Analyzing the average marginal effects estimated from the baseline endogenous probit (column 2 of Table 5), we find that having low income and education levels and being risk averse significantly reduce over-indebtedness probability. Moreover, we point out that objective financial knowledge significantly increases the probability of being over-indebted: a unit increase in the number of correct answers to financial knowledge questions raises over-indebtedness probability by more than 12.7 percentage points. This evidence seems to be at odds with the findings of French and McKillop [62] and Meyll and Pauls [63], which indicate that higher levels of financial 
knowledge are associated with lower debt burdens and a lower over-indebtedness probability. However, it should be kept in mind that in our analysis we consider a self-reported measure of over-indebtedness, while the above-mentioned studies consider objective measures of excessive indebtedness based on either debt-servicing ratios or arrears indicators.

Table 4. The determinants of having invested in a fraud: Average marginal effects.

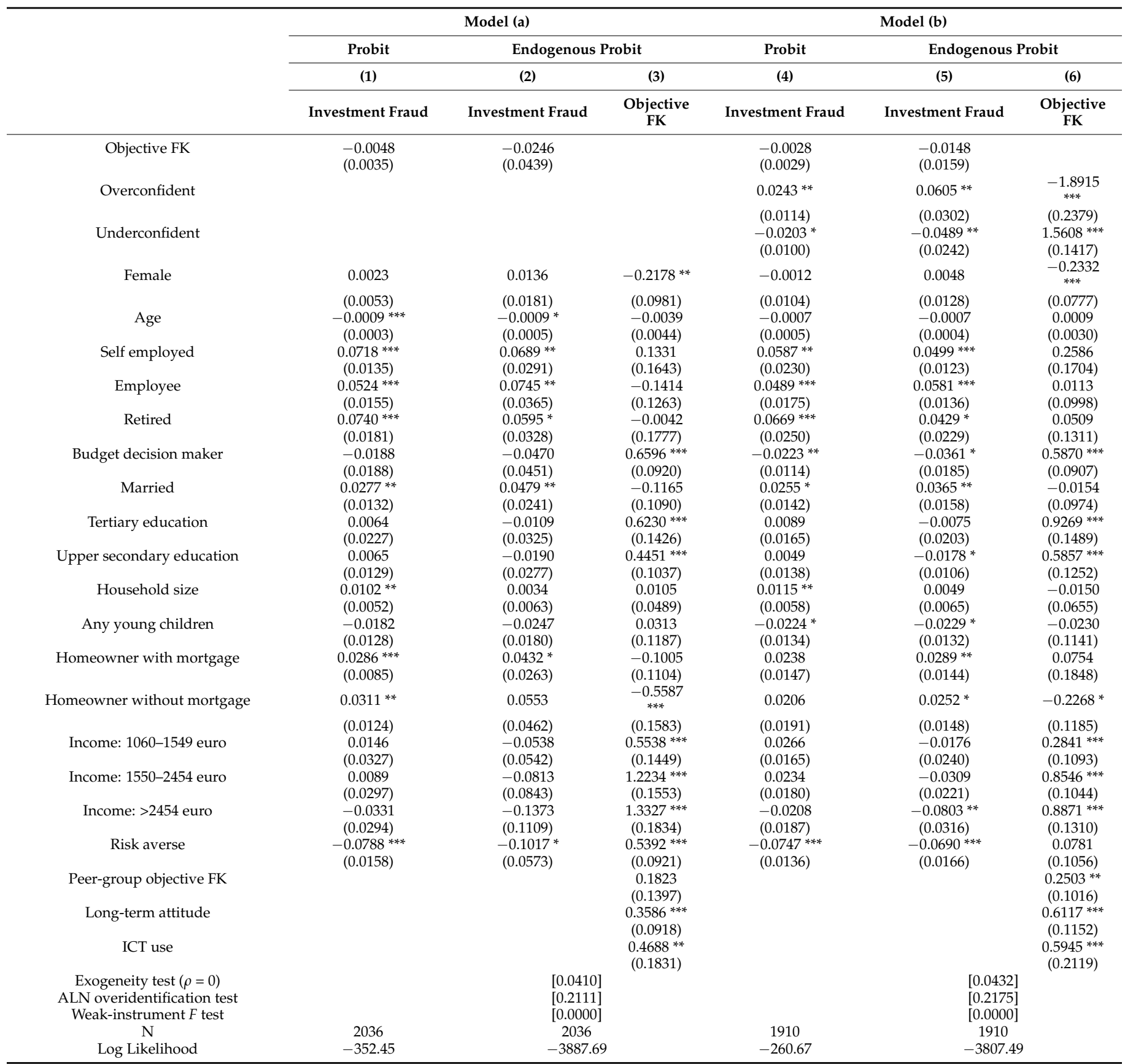

Notes: The Table reports the average marginal effects on the probability of having invested in a fraud, estimated from standard and endogenous probit models. Estimated average marginal effects on the number of correct answers to financial knowledge questions are also reported in columns (3) and (6). All the regressions include macro area and municipality size dummies. Robust standard errors, clustered by macro area and age class, are reported in parentheses below the estimates. The $p$-values of the exogeneity test, the Amemiya-Lee-Newey overidentification test, and the $F$ test for weak instruments are reported in square brackets. ${ }^{* * *},{ }^{* *}$, and ${ }^{*}$ denote significance at 1,5 , and $10 \%$ levels, respectively. Source: Own elaboration on data from the Bank of Italy. 
Table 5. The determinants of over-indebtedness: Average marginal effects.

\begin{tabular}{|c|c|c|c|c|c|c|}
\hline & \multicolumn{3}{|c|}{ Model (a) } & \multicolumn{3}{|c|}{ Model (b) } \\
\hline & \multirow{2}{*}{$\begin{array}{c}\text { Probit } \\
(1)\end{array}$} & \multicolumn{2}{|c|}{ Endogenous Probit } & \multirow{2}{*}{$\begin{array}{c}\text { Probit } \\
(4)\end{array}$} & \multicolumn{2}{|c|}{ Endogenous Probit } \\
\hline & & (2) & (3) & & (5) & (6) \\
\hline & Over-Indebted & Over-Indebted & Objective FK & Over-Indebted & Over-Indebted & Objective FK \\
\hline \multirow[t]{2}{*}{ Objective FK } & -0.0010 & $0.1272 * * *$ & & 0.0032 & $0.1025^{* * *}$ & \\
\hline & $(0.0041)$ & $(0.0141)$ & & $(0.0051)$ & $(0.0251)$ & \\
\hline \multirow[t]{2}{*}{ Overconfident } & & & & $0.0485^{* * *}$ & $0.2376^{* * *}$ & $-1.8965^{* * *}$ \\
\hline & & & & $(0.0159)$ & $(0.0485)$ & (0.1805) \\
\hline \multirow[t]{2}{*}{ Underconfident } & & & & -0.0012 & $-0.1486^{* * *}$ & $1.5554^{* * *}$ \\
\hline & & & & $(0.0153)$ & $(0.0477)$ & $(0.1317)$ \\
\hline \multirow[t]{2}{*}{ Female } & -0.0152 & 0.0221 & $-0.2045^{* *}$ & -0.0153 & 0.0127 & $-0.2199^{* * *}$ \\
\hline & $(0.0124)$ & $(0.0216)$ & $(0.0966)$ & $(0.0133)$ & $(0.0217)$ & $(0.0739)$ \\
\hline \multirow[t]{2}{*}{ Age } & $-0.0011^{* *}$ & 0.0000 & -0.0034 & $-0.0010 * *$ & -0.0007 & 0.0013 \\
\hline & $(0.0004)$ & $(0.0008)$ & $(0.0047)$ & $(0.0005)$ & $(0.0007)$ & $(0.0034)$ \\
\hline \multirow[t]{2}{*}{ Self employed } & 0.0149 & -0.0087 & 0.1414 & 0.0101 & -0.0182 & 0.2623 \\
\hline & $(0.0225)$ & $(0.0273)$ & $(0.1759)$ & $(0.0217)$ & $(0.0303)$ & $(0.2070)$ \\
\hline \multirow[t]{2}{*}{ Employee } & -0.0051 & 0.0147 & -0.1306 & -0.0017 & -0.0011 & 0.0174 \\
\hline & $(0.0204)$ & $(0.0284)$ & $(0.1571)$ & $(0.0210)$ & $(0.0270)$ & $(0.1598)$ \\
\hline \multirow[t]{2}{*}{ Retired } & $0.0510 * *$ & 0.0403 & 0.0002 & $0.0466^{* *}$ & 0.0445 & 0.0564 \\
\hline & $(0.0198)$ & $(0.0312)$ & $(0.1571)$ & $(0.0206)$ & $(0.0283)$ & $(0.1383)$ \\
\hline \multirow{2}{*}{ Budget decision maker } & $-0.0252 *$ & $-0.1165^{* * *}$ & $0.6896^{* * *}$ & -0.0264 * & $-0.1021^{* * *}$ & $0.6024^{* * *}$ \\
\hline & $(0.0133)$ & $(0.0180)$ & $(0.1258)$ & $(0.0140)$ & (0.0199) & $(0.0864)$ \\
\hline \multirow[t]{2}{*}{ Married } & 0.0122 & 0.0220 & -0.1145 & 0.0092 & 0.0080 & -0.0142 \\
\hline & $(0.0178)$ & $(0.0138)$ & $(0.1179)$ & $(0.0196)$ & $(0.0213)$ & $(0.0839)$ \\
\hline \multirow[t]{2}{*}{ Tertiary education } & -0.0264 & $-0.1053^{* * *}$ & $0.6263^{* * *}$ & -0.0366 & $-0.1358^{* * *}$ & $0.9268^{* * *}$ \\
\hline & $(0.0281)$ & $(0.0336)$ & $(0.1552)$ & $(0.0281)$ & $(0.0355)$ & $(0.1528)$ \\
\hline \multirow[t]{2}{*}{ Upper secondary education } & -0.0037 & $-0.0656^{* *}$ & $0.4507^{* * *}$ & -0.0160 & $-0.0824 * * *$ & $0.5879 * * *$ \\
\hline & $(0.0207)$ & $(0.0285)$ & $(0.1452)$ & $(0.0210)$ & $(0.0307)$ & $(0.1339)$ \\
\hline Household size & 0.0003 & -0.0010 & 0.0085 & -0.0011 & 0.0005 & -0.0163 \\
\hline & $(0.0065)$ & $(0.0102)$ & $(0.0697)$ & $(0.0068)$ & $(0.0097)$ & $(0.0612)$ \\
\hline Any young children & -0.0022 & -0.0070 & 0.0302 & -0.0008 & 0.0002 & -0.0246 \\
\hline & $(0.0177)$ & $(0.0174)$ & $(0.1061)$ & $(0.0175)$ & $(0.0183)$ & $(0.0946)$ \\
\hline Homeowner with mortgage & $-0.0371^{* *}$ & -0.0218 & -0.0949 & $-0.0346^{*}$ & $-0.0524^{*}$ & 0.0771 \\
\hline & $(0.0174)$ & $(0.0298)$ & $(0.2033)$ & $(0.0184)$ & $(0.0280)$ & $(0.1744)$ \\
\hline $\begin{array}{c}\text { Homeowner without } \\
\text { mortgage }\end{array}$ & 0.0188 & $0.0822 * *$ & $-0.5538^{* * *}$ & 0.0178 & 0.0370 & -0.2245 \\
\hline & $(0.0279)$ & $(0.0353)$ & $(0.1867)$ & $(0.0292)$ & $(0.0384)$ & $(0.1614)$ \\
\hline Income: $1060-1549$ euro & 0.0313 & $-0.0543 *$ & $0.5468^{* * *}$ & 0.0311 & -0.0040 & $0.2802 *$ \\
\hline & $(0.0191)$ & $(0.0303)$ & $(0.1658)$ & $(0.0192)$ & $(0.0335)$ & $(0.1457)$ \\
\hline Income: 1550-2454 euro & -0.0071 & $-0.1638^{* * *}$ & $1.2190 * * *$ & 0.0001 & $-0.0919 * *$ & $0.8534^{* * *}$ \\
\hline & $(0.0230)$ & $(0.0324)$ & $(0.1815)$ & $(0.0246)$ & $(0.0416)$ & $(0.1477)$ \\
\hline Income: >2454 euro & -0.0281 & $-0.1961^{* * *}$ & $1.3400^{* * *}$ & -0.0240 & $-0.1233^{* * *}$ & $0.8932^{* * *}$ \\
\hline & $(0.0225)$ & $(0.0408)$ & $(0.2584)$ & $(0.0246)$ & $(0.0468)$ & $(0.2050)$ \\
\hline Risk averse & $-0.0748^{* * *}$ & $-0.1201^{* * *}$ & $0.5400^{* * *}$ & $-0.0687^{* * *}$ & $-0.0746^{* * *}$ & 0.0784 \\
\hline & $(0.0162)$ & $(0.0191)$ & $(0.0893)$ & $(0.0162)$ & $(0.0209)$ & $(0.0990)$ \\
\hline Peer-group objective FK & & & $0.2384^{* * *}$ & & & $0.3045^{* * *}$ \\
\hline & & & $(0.0770)$ & & & $(0.0704)$ \\
\hline Long-term attitude & & & $0.3648^{* * *}$ & & & $0.6102^{* * *}$ \\
\hline & & & $(0.0840)$ & & & $(0.0951)$ \\
\hline ICT use & & & 0.2069 & & & $0.4694^{* *}$ \\
\hline & & & $(0.1944)$ & & & $(0.2025)$ \\
\hline Exogeneity test $(\rho=0)$ & & {$[0.1$} & & & {$[0.1$} & \\
\hline ALN overidentification test & & {$[0$.} & & & {$[0$.} & \\
\hline Weak-instrument $F$ test & & {$[0.1$} & & & {$[0.1$} & \\
\hline $\mathrm{N}$ & 2036 & & & 1910 & & \\
\hline Log Likelihood & -556.32 & -47 & .36 & -523.23 & -40 & .40 \\
\hline
\end{tabular}

Notes: The table reports the average marginal effects on the probability of being over-indebted, estimated from standard and endogenous probit models. Estimated average marginal effects on the number of correct answers to financial knowledge questions are also reported in columns (3) and (6). All the regressions include macro area and municipality size dummies. Robust standard errors, clustered by macro area and age class, are reported in parentheses below the estimates. The $p$-values of the exogeneity test, the Amemiya-Lee-Newey overidentification test, and the $F$ test for weak instruments are reported in square brackets. ${ }^{* * *}$, **, and ${ }^{*}$ denote significance at 1,5 , and $10 \%$ levels, respectively Source: Own elaboration on data from the Bank of Italy.

The empirical evidence obtained can be thus explained by the fact that more financially knowledgeable individuals are not only more likely to participate in investment and credit markets, but they are also better able to correctly judge their debt position. These two 
mechanisms may contribute to determining the positive impact of objective financial knowledge on the probability of self-reporting an excessive debt burden. The relevance of the first mechanism can be tested by modelling individuals' self-selection into the credit market (i.e., by jointly analyzing the probability of having debt and the conditional probability of being over-indebted). Unfortunately, the available data do not allow us to carry out such analysis and account for potential selectivity bias.

Extending the model to account for the effect of confidence, we find that the positive impact of objective financial knowledge remains confirmed and that misperception of one's own financial abilities significantly affects the probability of being over-indebted. In particular, controlling for objective knowledge and other socio-demographic characteristics, overconfident individuals are about $24 \%$ more likely to report being excessively indebted than those who correctly assess their financial competencies; conversely, those who understate their financial knowledge are about 15\% less likely to be over-indebted than the control group. The evidence obtained further stresses the adverse impact of overconfidence bias on the sustainability of individual financial choices, supporting the findings of Lusardi and Tufano [4] and Gathergood [64]. Excessive self-confidence, combined with lack of skill or cognition, significantly impairs individuals' ability to manage their finances correctly and leads to unsustainable levels of debt. Empirical results also highlight individuals who are responsible for the household's budget and those with mortgage loan experience have a significantly lower probability of being over-indebted. This evidence confirms the beneficial role of financial and credit experience on debt sustainability, coherently with the findings of Lusardi and Tufano [4] and Kurowski [41],

\subsection{Preference for Socially and Environmentally Responsible Financial Companies}

Finally, we analyze individuals' attitudes towards environmentally and socially responsible financial companies. Table 6 reports results on the drivers of the probability of preferring financial companies that have a strong ethical stance, obtained from standard and endogenous probit models. Even in this case, financial knowledge is endogenously determined with respect to preferences for responsible financial companies and instrument validity is confirmed.

From the average marginal effects estimated from the baseline endogenous probit (column 2 of Table 6), we find that women are about 3\% more likely to prefer ethical financial companies than men. Similarly, older individuals and those with lower income levels, higher education attainment, and lower risk aversion are characterized by a greater preference for financial companies with an ethical stance.

Objective financial knowledge significantly contributes to increasing the likelihood of preferring environmentally and socially responsible financial companies. Specifically, a unit increase in the number of correct responses to financial knowledge questions raises the probability of dealing with ethical financial companies by more than 14 percentage points. As it can be noticed, accounting for the endogeneity of financial knowledge allows avoiding downwardly biased estimates of its effect on the preference for ethical financial companies: the corresponding marginal effect estimated from the standard (exogenous) probit regression is more than 4 times lower $(3.33 \%)$ than that obtained from the endogenous model. This result provides strong empirical evidence that greater preference for environmentally and socially responsible financial companies characterizes more financially knowledgeable individuals and suggests that inadequate financial knowledge represents a significant barrier to individuals' participation in socially responsible investments. Coherently with Phillips and Johnson [14], Gutsche and Zwergel [16], and Gutsche et al. [17], our findings point out that improvements in financial knowledge levels may significantly contribute to increasing trust in providers of sustainable investment products, overcoming initial entry hurdles for individual investors, and encouraging participation in the socially responsible investment market. 
Table 6. The determinants of preferring ethical financial companies: Average marginal effects.

\begin{tabular}{|c|c|c|c|c|c|c|}
\hline & \multicolumn{3}{|c|}{ Model (a) } & \multicolumn{3}{|c|}{ Model (b) } \\
\hline & \multirow{3}{*}{$\begin{array}{c}\text { Probit } \\
(1) \\
\text { ESR Attitude }\end{array}$} & \multicolumn{2}{|c|}{ Endogenous Probit } & \multirow{3}{*}{$\begin{array}{c}\text { Probit } \\
(4) \\
\text { ESR Attitude }\end{array}$} & \multicolumn{2}{|c|}{ Endogenous Probit } \\
\hline & & (2) & (3) & & (5) & (6) \\
\hline & & ESR Attitude & Objective FK & & ESR Attitude & Objective FK \\
\hline \multirow[t]{2}{*}{ Objective FK } & $0.0333 * * *$ & $0.1433^{* * *}$ & & $0.0448^{* * *}$ & $0.1550 * * *$ & \\
\hline & $(0.0034)$ & $(0.0026)$ & & $(0.0055)$ & $(0.0084)$ & \\
\hline \multirow[t]{2}{*}{ Overconfident } & & & & $0.1042 * * *$ & $0.3028^{* * *}$ & $-1.8999 * * *$ \\
\hline & & & & $(0.0351)$ & $(0.0288)$ & (0.1839) \\
\hline \multirow[t]{2}{*}{ Underconfident } & & & & -0.0310 & $-0.2081^{* * *}$ & $1.5543^{* * *}$ \\
\hline & & & & $(0.0262)$ & $(0.0210)$ & $(0.1332)$ \\
\hline \multirow[t]{2}{*}{ Female } & -0.0191 & 0.0308 * & $-0.2404^{* *}$ & -0.0156 & 0.0304 ** & $-0.2417^{* * *}$ \\
\hline & $(0.0147)$ & $(0.0161)$ & (0.1010) & (0.0159) & $(0.0151)$ & (0.0785) \\
\hline \multirow[t]{2}{*}{ Age } & 0.0009 & $0.0012 * *$ & -0.0044 & 0.0008 & 0.0009 & 0.0007 \\
\hline & $(0.0011)$ & $(0.0005)$ & $(0.0049)$ & $(0.0011)$ & $(0.0007)$ & $(0.0034)$ \\
\hline \multirow[t]{2}{*}{ Self employed } & $0.0561 * *$ & -0.0049 & 0.1410 & 0.0425 & -0.0165 & 0.2627 \\
\hline & $(0.0253)$ & $(0.0263)$ & $(0.1781)$ & $(0.0264)$ & $(0.0352)$ & $(0.2060)$ \\
\hline \multirow[t]{2}{*}{ Employee } & 0.0085 & 0.0206 & -0.1350 & 0.0038 & 0.0007 & 0.0164 \\
\hline & $(0.0276)$ & $(0.0217)$ & $(0.1569)$ & $(0.0263)$ & $(0.0216)$ & $(0.1580)$ \\
\hline \multirow[t]{2}{*}{ Retired } & -0.0081 & 0.0002 & -0.0210 & -0.0215 & -0.0169 & 0.0428 \\
\hline & $(0.0429)$ & $(0.0188)$ & $(0.1590)$ & $(0.0425)$ & $(0.0254)$ & $(0.1412)$ \\
\hline \multirow[t]{2}{*}{ Budget decision maker } & $0.0603^{* * *}$ & $-0.0793^{* * *}$ & $0.6969^{* * *}$ & $0.0522 * *$ & $-0.0619 * * *$ & $0.6089 * * *$ \\
\hline & $(0.0214)$ & (0.0184) & $(0.1309)$ & $(0.0229)$ & $(0.0160)$ & $(0.0910)$ \\
\hline \multirow[t]{2}{*}{ Married } & $0.0554^{*}$ & $0.0322^{*}$ & -0.1174 & 0.0416 & 0.0239 & -0.0167 \\
\hline & $(0.0299)$ & $(0.0179)$ & $(0.1182)$ & $(0.0309)$ & $(0.0190)$ & $(0.0850)$ \\
\hline \multirow[t]{2}{*}{ Tertiary education } & $0.1588^{* * *}$ & -0.0331 & $0.6310^{* * *}$ & $0.1394^{* * *}$ & -0.0382 & $0.9289 * * *$ \\
\hline & $(0.0342)$ & $(0.0258)$ & $(0.1537)$ & $(0.0342)$ & $(0.0306)$ & $(0.1517)$ \\
\hline \multirow[t]{2}{*}{ Upper secondary education } & $0.0657^{* *}$ & $-0.0409^{* *}$ & $0.4551^{* * *}$ & $0.0444 *$ & $-0.0539 * *$ & $0.5915^{* * *}$ \\
\hline & $(0.0262)$ & $(0.0201)$ & $(0.1431)$ & $(0.0244)$ & $(0.0225)$ & $(0.1323)$ \\
\hline Household size & 0.0035 & -0.0003 & 0.0094 & 0.0040 & 0.0042 & -0.0160 \\
\hline & $(0.0095)$ & $(0.0096)$ & $(0.0698)$ & $(0.0094)$ & $(0.0094)$ & $(0.0613)$ \\
\hline Any young children & -0.0041 & -0.0054 & 0.0357 & -0.0046 & 0.0012 & -0.0204 \\
\hline & $(0.0214)$ & $(0.0137)$ & $(0.1071)$ & $(0.0224)$ & $(0.0152)$ & $(0.0962)$ \\
\hline Homeowner with mortgage & 0.0092 & 0.0119 & -0.0934 & 0.0030 & -0.0156 & 0.0789 \\
\hline & $(0.0258)$ & $(0.0282)$ & $(0.2049)$ & $(0.0281)$ & $(0.0303)$ & $(0.1746)$ \\
\hline $\begin{array}{l}\text { Homeowner without } \\
\text { mortgage }\end{array}$ & $0.1001 * *$ & $0.1048^{* * *}$ & $-0.5574^{* * *}$ & $0.0937^{* *}$ & $0.0804^{* * *}$ & -0.2264 \\
\hline & $(0.0395)$ & $(0.0270)$ & $(0.1849)$ & $(0.0388)$ & $(0.0280)$ & $(0.1606)$ \\
\hline Income: 1060-1549 euro & 0.0555 & $-0.0550^{* * *}$ & $0.5535^{* * *}$ & 0.0598 * & -0.0052 & $0.2821 *$ \\
\hline & $(0.0341)$ & $(0.0204)$ & $(0.1657)$ & $(0.0355)$ & $(0.0246)$ & $(0.1452)$ \\
\hline Income: 1550-2454 euro & 0.0174 & $-0.1516^{* * *}$ & $1.2221^{* * *}$ & 0.0318 & $-0.0913^{* * *}$ & $0.8519 * * *$ \\
\hline & $(0.0276)$ & $(0.0242)$ & $(0.1821)$ & $(0.0295)$ & $(0.0295)$ & $(0.1477)$ \\
\hline Income: >2454 euro & 0.0598 * & $-0.1534^{* * *}$ & $1.3407^{* * *}$ & $0.0759 * *$ & -0.0726 & $0.8905^{* * *}$ \\
\hline & $(0.0309)$ & $(0.0377)$ & $(0.2583)$ & $(0.0362)$ & $(0.0444)$ & $(0.2045)$ \\
\hline Risk averse & $-0.0479 * * *$ & $-0.0815^{* * *}$ & $0.5414^{* * *}$ & $-0.0336 *$ & -0.0225 & 0.0822 \\
\hline & $(0.0177)$ & $(0.0139)$ & $(0.0916)$ & $(0.0194)$ & $(0.0176)$ & $(0.0995)$ \\
\hline Peer-group objective FK & & & $0.1176^{*}$ & & & $0.2253^{* * *}$ \\
\hline & & & $(0.0624)$ & & & $(0.0692)$ \\
\hline Long-term attitude & & & $0.3860^{* * *}$ & & & $0.6479 * * *$ \\
\hline & & & $(0.1009)$ & & & $(0.0893)$ \\
\hline ICT use & & & 0.1067 & & & $0.3611^{*}$ \\
\hline & & & $(0.1761)$ & & & $(0.2184)$ \\
\hline Exogeneity test $(\rho=0)$ & & & & & & \\
\hline ALN overidentification test & & & & & & \\
\hline Weak-instrument $F$ test & & & & & & \\
\hline $\mathrm{N}$ & 2036 & & & 1910 & & \\
\hline Log Likelihood & -1004.35 & -4 & .44 & -945.41 & -4 & .71 \\
\hline
\end{tabular}

Notes: The table reports the average marginal effects on the probability of preferring socially and environmentally responsible financial companies, estimated from standard and endogenous probit models. Estimated average marginal effects on the number of correct answers to financial knowledge questions are also reported in columns (3) and (6). All the regressions include macro area and municipality size dummies. Robust standard errors, clustered by macro area and age class, are reported in parentheses below the estimates. The $p$-values of the exogeneity test, the Amemiya-Lee-Newey overidentification test, and the $F$ test for weak instruments are reported in square brackets. $* * * * *$, and $*$ denote significance at 1,5 , and $10 \%$ levels, respectively. Source: Own elaboration on data from the Bank of Italy.

Results from the extended specification (model (b)) confirm the significant role of objective financial knowledge and also suggest that self-confidence in one's own financial 
competencies affects individual preferences for ethical financial companies. In particular, overconfident individuals are not only more likely to invest in financial assets, but they have greater preference for environmentally and socially responsible financial companies than individuals who correctly self-report their financial abilities. Similarly, those who underestimated their financial knowledge are less likely to prefer dealing with ethical financial companies (by about 21 percentage points), as their lower propensity to participate in financial markets and their passive investment behavior may contribute to reducing their awareness about environmentally and socially responsible investing. Since sustainable investment products are more complex than conventional products, information and search costs are higher compared to conventional investing and this may represent an important barrier for those individuals who are, by their very nature, less interested in pursuing financial investment.

\section{Conclusions}

This paper contributes to the existing literature by providing evidence about the role of financial knowledge and confidence in shaping individual financial market participation, sustainable debt behavior, and preferences for socially and environmentally responsible financial companies.

In line with previous empirical studies $[30,34,46]$, we find that objective financial knowledge exerts a positive and statistically significant effect on financial market participation. Furthermore, we point out that overconfident individuals tend to engage in excess trading, being more likely to invest in financial assets than similar individuals who correctly assess their competencies, whereas underconfident individuals inappropriately choose passive investment patterns and refrain from riskier investments. This evidence supports the findings of previous literature $[10,28,29]$ and suggests that the systematic misjudgment of one's own financial abilities may lead to negative consequences on financial planning and wealth accumulation.

Focusing on risky investment behavior and analyzing, in particular, the role of financial knowledge and confidence on an individual's vulnerability to investment fraud, our results demonstrate that objective financial knowledge has no significant effect on the probability of being a victim of financial fraud; nevertheless, individuals who are more likely to invest in financial assets are also more exposed to financial scams. Confidence biases in assessing one's own financial competencies emerge as significant determinants of individual susceptibility to investment fraud. In particular, we find that overconfident individuals are more likely to have experienced fraud than those correctly assessing their capabilities; at the same time, individuals who understate their financial abilities are less likely to expose themselves to hazardous financial behaviors. This evidence clearly points out the detrimental role of financial knowledge overconfidence on financial decision-making, confirming the results of previous studies $[7,27,61]$. The analysis of debt sustainability highlights that overconfidence and less financial knowledge significantly impair individuals' ability to manage their finances correctly and lead to unsustainable levels of debt.

Finally, objective financial knowledge significantly contributes to increasing the likelihood of preferring environmentally and socially responsible financial companies, suggesting that inadequate financial knowledge represents a significant barrier to individuals participation in socially responsible investments. Coherently, those who underestimated their financial knowledge are less likely to prefer dealing with ethical financial companies, as their lower level of investment experience and their passive investment behavior may reduce their awareness of environmentally and socially responsible investments and their understanding of sustainable financial products, usually characterized by a more complex structure than conventional products.

Our main results provide significant insights into the crucial role played by financial knowledge and self-confidence in improving individual well-being and social and environmental wealth. Therefore, programs aimed at increasing the average level of financial knowledge and the awareness of one's own financial competencies could significantly 
contribute to reduce riskier financial behaviors and build a culture of sustainability, both maintaining debt at sustainable levels and encouraging the choice of ethical financial companies and sustainable financial products. These policies could be pursued through the implementation of financial education programs starting from primary schools and through financial inclusion and information plans aimed at the most vulnerable and fragile groups in society (e.g., women, young people, persons with low income levels). Moreover, the reduction of information deficit and asymmetries, by means of targeted and transparent information documents and contracts, could improve understanding of the financial structure of socially and environmentally sustainable investments and the performance of this kind of investment. Since individual investors are prone to judgment and decision-making errors in their investment choices, the promotion of cost-controlled financial advisory activities could also ensure greater awareness of investment choices and a more sustainable debt burden in the medium-long term. Nevertheless, policy interventions supporting environmental values and the ecological political identification of a country could also play a significant role in incentivizing individual sustainable investment behavior.

Author Contributions: The authors equally contributed to the development of this research. Both authors have read and agreed to the published version of the manuscript.

Funding: This research was conducted within the project "Bank management, finance and sustainability" financed by the University of Perugia (Fondo Ricerca di Base, 2019).

Conflicts of Interest: The authors declare no conflict of interest.

\section{Appendix A}

Table A1. Variable definitions.

\begin{tabular}{|c|c|}
\hline Variable & Definition \\
\hline \multicolumn{2}{|r|}{ P } \\
\hline Financial investment & $\begin{array}{l}\text { Equals } 1 \text { if the respondent, in the last two years, has invested in stocks and shares, public and private bonds, mutual and } \\
\text { pension plans, cryptocurrencies or ICOs; } 0 \text { otherwise }\end{array}$ \\
\hline Investment fraud & Equals 1 if the respondent accepted advice to invest in a financial product that was later found to be a scam; 0 otherwise \\
\hline Over-indebted & Equals 1 if the respondent agrees or totally agrees to the statement "I have too much debt right now"; 0 otherwise \\
\hline ESR attitude & $\begin{array}{l}\text { Equals } 1 \text { if the respondent agrees or totally agrees to the statement "I prefer to use financial companies that have a strong } \\
\text { ethical stance"; } 0 \text { otherwise }\end{array}$ \\
\hline \multicolumn{2}{|l|}{$\begin{array}{l}\text { (b) Explanatory variables } \\
\text { (b1) Financial knowledge and confidence }\end{array}$} \\
\hline Objective FK & Number of correct answers to financial knowledge questions \\
\hline Subjective FK & Self-rated financial knowledge, measured on a scale from 1 (very low) to 5 (very high) \\
\hline Overconfident & Equals 1 if the respondent's Subjective FK is above the sample mean and Objective FK is below the sample mean; 0 otherwise \\
\hline \multicolumn{2}{|l|}{ (b2) Other individual characteristics } \\
\hline Female & Equals 1 if the respondent is a woman; 0 otherwise \\
\hline Age & Age of the respondent in years \\
\hline Self-employed & Equals 1 if the respondent is self-employed; 0 otherwise \\
\hline Employee & Equals 1 if the respondent is an employee; 0 otherwise \\
\hline Retired & Equals 1 if the respondent is retired; 0 otherwise \\
\hline Budget decision maker & Equals 1 if the respondent is the person responsible for the household's budget and expenditures; 0 otherwise \\
\hline Married & Equals 1 if the respondent is married; 0 otherwise \\
\hline Tertiary education & Equals 1 if the respondent has a tertiary education; 0 otherwise \\
\hline Upper secondary education & Equals 1 if the respondent has an upper secondary education; 0 otherwise \\
\hline Household size & Number of household members \\
\hline Any young children & Equals 1 if at least one child below 18 years lives in the household; 0 otherwise \\
\hline Homeowner with mortgage & Equals 1 if the respondent is a homeowner with mortgage; 0 otherwise \\
\hline Homeowner without mortgage & Equals 1 if the respondent is a homeowner without mortgage; 0 otherwise \\
\hline Income: $1060-1549$ euro & Total household net monthly disposable income between 1060 and 1549 euro \\
\hline Income: $1550-2454$ euro & Total household net monthly disposable income between 1550 and 2454 euro \\
\hline Income: $>2454$ euro & Total household net monthly disposable income above 2454 euro \\
\hline Risk averse & $\begin{array}{l}\text { Equals } 1 \text { if the respondent disagrees or totally disagrees to the statement "I am prepared to risk some of my own money } \\
\text { when saving or making an investment"; } 0 \text { otherwise }\end{array}$ \\
\hline \multicolumn{2}{|r|}{ (1) } \\
\hline Peer-group objective FK & $\begin{array}{l}\text { Average number of correct answers to financial knowledge questions of the other individuals of the same gender, living in } \\
\text { the same macro-area and belonging to the same age class of the respondents }\end{array}$ \\
\hline Long-term attitude & $\begin{array}{l}\text { Equals } 1 \text { if the respondent disagrees or totally disagrees to the statement "I tend to live for today and let tomorrow take } \\
\text { care of itself" and/or if the respondent agrees or totally agrees to the statement "I set long term financial goals and strive to } \\
\text { achieve them"; } 0 \text { otherwise }\end{array}$ \\
\hline ICT use & $\begin{array}{l}\text { Equals } 1 \text { if the respondent use ICT instruments (i.e., banking apps or money management tools on a computer, mobile } \\
\text { phone and/or tablet) to keep note of payment deadlines and track income and expenses; } 0 \text { otherwise }\end{array}$ \\
\hline
\end{tabular}


Table A2. Descriptive statistics disaggregated by individual and household characteristics.

\begin{tabular}{|c|c|c|c|c|c|c|}
\hline & $\begin{array}{c}\text { Financial } \\
\text { Investment }\end{array}$ & $\begin{array}{l}\text { Investment } \\
\text { Fraud }\end{array}$ & Over-Indebted & ESR Attitude & Objective FK & Subjective FK \\
\hline \multicolumn{7}{|l|}{ Gender } \\
\hline Male & 0.114 & 0.055 & 0.101 & 0.266 & 4.063 & 2.347 \\
\hline $\begin{array}{l}\text { Female } \\
\text { Age }\end{array}$ & 0.074 & \multicolumn{5}{|c|}{ Age } \\
\hline Less than 25 & 0.009 & 0.026 & 0.057 & 0.173 & 3.93 & 1.948 \\
\hline 25-34 & 0.109 & 0.063 & 0.102 & 0.236 & 3.881 & 2.204 \\
\hline $35-44$ & 0.109 & 0.075 & 0.089 & 0.305 & 4.225 & 2.436 \\
\hline $45-54$ & 0.131 & 0.036 & 0.092 & 0.296 & 4.09 & 2.44 \\
\hline $55-64$ & 0.111 & 0.041 & 0.079 & 0.272 & 4.023 & 2.261 \\
\hline 65 and above & 0.063 & 0.045 & 0.066 & 0.169 & 3.588 & 1.92 \\
\hline \multicolumn{7}{|l|}{ Working status } \\
\hline Self employed & 0.174 & 0.064 & 0.073 & 0.372 & 4.533 & 2.618 \\
\hline Employee & 0.125 & 0.062 & 0.086 & 0.286 & 4.076 & 2.438 \\
\hline Retired & 0.085 & 0.044 & 0.077 & 0.172 & 3.659 & 1.935 \\
\hline $\begin{array}{l}\text { Unemployed/Not in } \\
\text { labour force }\end{array}$ & 0.009 & 0.023 & 0.079 & 0.183 & 3.675 & 1.887 \\
\hline \multicolumn{7}{|l|}{$\begin{array}{l}\text { Household budget } \\
\text { decision making }\end{array}$} \\
\hline Budget decision maker & 0.159 & 0.034 & 0.060 & 0.312 & 4.380 & 2.415 \\
\hline $\begin{array}{c}\text { Not budget decision } \\
\text { maker }\end{array}$ & 0.042 & 0.060 & 0.097 & 0.185 & 3.565 & 2.022 \\
\hline \multicolumn{7}{|l|}{ Marital status } \\
\hline Married & 0.118 & 0.060 & 0.086 & 0.283 & 3.990 & 2.282 \\
\hline $\begin{array}{l}\text { Not married } \\
\text { Education }\end{array}$ & 0.066 & 0.035 & 0.075 & 0.194 & 3.850 & 2.109 \\
\hline $\begin{array}{l}\text { Less than upper } \\
\text { secondary }\end{array}$ & 0.047 & 0.039 & 0.079 & 0.148 & 3.490 & 1.822 \\
\hline Upper secondary & 0.116 & 0.061 & 0.090 & 0.270 & 4.083 & 2.372 \\
\hline Tertiary & 0.131 & 0.039 & 0.063 & 0.356 & 4.405 & 2.559 \\
\hline \multicolumn{7}{|l|}{ Household size } \\
\hline 1 person & 0.078 & 0.013 & 0.056 & 0.152 & 3.603 & 2.100 \\
\hline 2 persons & 0.119 & 0.058 & 0.096 & 0.212 & 3.862 & 2.145 \\
\hline 3 persons & 0.106 & 0.082 & 0.105 & 0.311 & 3.846 & 2.263 \\
\hline 4 persons & 0.066 & 0.035 & 0.057 & 0.284 & 4.330 & 2.332 \\
\hline 5 persons and more & 0.023 & 0.000 & 0.054 & 0.234 & 4.237 & 2.075 \\
\hline \multicolumn{7}{|l|}{ Household composition } \\
\hline Any young children & 0.130 & 0.049 & 0.079 & 0.335 & 4.234 & 2.370 \\
\hline $\begin{array}{l}\text { No young children } \\
\text { Housing tenure }\end{array}$ & 0.084 & 0.048 & 0.081 & 0.218 & 3.846 & 2.158 \\
\hline $\begin{array}{l}\text { Homeowner without } \\
\text { mortgage }\end{array}$ & 0.111 & 0.051 & 0.066 & 0.244 & 4.036 & 2.248 \\
\hline $\begin{array}{l}\text { Homeowner with } \\
\text { mortgage }\end{array}$ & 0.107 & 0.081 & 0.132 & 0.368 & 3.646 & 2.412 \\
\hline \multirow{2}{*}{\multicolumn{7}{|c|}{$\begin{array}{l}\text { Household disposable } \\
\text { income }\end{array}$}} \\
\hline & & & & & & \\
\hline Less than 1060 euro & 0.005 & 0.027 & 0.081 & 0.103 & 2.997 & 1.755 \\
\hline 1060-1549 euro & 0.056 & 0.061 & 0.113 & 0.210 & 3.517 & 2.025 \\
\hline 1550-2454 euro & 0.113 & 0.061 & 0.069 & 0.232 & 4.271 & 2.327 \\
\hline 2455 euro and above & 0.165 & 0.025 & 0.052 & 0.367 & 4.509 & 2.496 \\
\hline \multicolumn{7}{|l|}{ Risk aversion } \\
\hline Risk averse & 0.068 & 0.013 & 0.051 & 0.217 & 4.049 & 2.027 \\
\hline Non risk averse & 0.133 & 0.105 & 0.128 & 0.28 & 3.723 & 2.486 \\
\hline \multicolumn{7}{|l|}{ Area of residence } \\
\hline North & 0.124 & 0.056 & 0.072 & 0.258 & 3.965 & 2.321 \\
\hline Centre & 0.123 & 0.046 & 0.087 & 0.251 & 4.076 & 2.169 \\
\hline South & 0.034 & 0.039 & 0.088 & 0.213 & 3.779 & 2.052 \\
\hline Total & 0.093 & 0.048 & 0.081 & 0.241 & 3.924 & 2.200 \\
\hline
\end{tabular}

Notes: The table reports average values of financial behavior indicators and objective and subjective financial knowledge disaggregated by individual and household characteristics, computed using sample weights. Source: Own elaboration on data from the Bank of Italy.

\section{References}

1. Hira, T.K. Promoting sustainable financial behaviour: Implications for education and research. Int. J. Consum. Stud. 2012, 36, 502-507. [CrossRef] 
2. Klapper, L.; Lusardi, A.; Panos, G.A. Financial literacy and its consequences: Evidence from Russia during the financial crisis. J. Bank. Financ. 2013, 37, 3904-3923. [CrossRef]

3. Xiao, J.J.; Ahn, S.Y.; Serido, J.; Shim, S. Earlier financial literacy and later financial behaviour of college students. Int. J. Consum. Stud. 2014, 38, 593-601. [CrossRef]

4. Lusardi, A.; Tufano, P. Debt literacy, financial experiences, and overindebtedness. J. Pension Econ. Financ. 2015, 14, 332-368. [CrossRef]

5. Lusardi, A.; Mitchell, O.S. Older Women's Labor Market Attachment, Retirement Planning, and Household Debt. In Women Working Longer: Increased Employment at Older Ages; Goldin, C., Lawrence, F.K., Eds.; University of Chicago Press: Chicago, IL, USA, 2018.

6. Clark, R.L.; Lusardi, A.; Mitchell, O.S. Financial Fragility during the COVID-19 Pandemic. AEA Pap. Proc. 2021, 111, 292-296. [CrossRef]

7. Van Raaij, W.F. Understanding Consumer Financial Behavior: Money Management in an Age of Financial Illiteracy; Palgrave Macmillan: New York, NY, USA, 2016.

8. Calcagno, R.; Monticone, C. Financial literacy and the demand for financial advice. J. Bank. Financ. 2015, 50, 363-380. [CrossRef]

9. Engels, C.; Kumar, K.; Philip, D. Financial literacy and fraud detection. Eur. J. Financ. 2020, 26, 420-442. [CrossRef]

10. Allgood, S.; Walstad, W.B. The effects of perceived and actual financial literacy on financial behaviors. Econ. Inq. 2016, 54, 675-697. [CrossRef]

11. Van Rooij, M.; Lusardi, A.; Alessie, R. Financial literacy, retirement planning, and household wealth. Econ. J. 2012, 122, 449-478. [CrossRef]

12. Lusardi, A.; Mitchell, O.S. How Ordinary Consumers Make Complex Economic Decisions: Financial Literacy and Retirement Readiness. Q. J. Financ. 2017, 7, 1750008. [CrossRef]

13. Fornero, E.; Monticone, C. Financial literacy and pension plan participation in Italy. J. Pension Econ. Financ. 2010, 10, 547-564. [CrossRef]

14. Getzner, M.; Grabner-Kraüter, S. Consumer preferences and marketing strategies for "green shares" Specifics of the Austrian market. Int. J. Bank Mark. 2004, 22, 260-278. [CrossRef]

15. Phillips, S.D.; Johnson, B. Inching to Impact: The Demand Side of Social Impact Investing. J. Bus. Ethics 2021, 168, 615-629. [CrossRef]

16. Gutsche, G.; Zwergel, B. Investment Barriers and Labeling Schemes for Socially Responsible Investments. Schmalenbach Bus. Rev. 2020, 72, 111-157. [CrossRef]

17. Gutsche, G.; Nakai, M.; Arimura, T.H. Revisiting the determinants of individual sustainable investment-The case of Japan. J. Behav. Exp. Financ. 2021, 30, 100497. [CrossRef]

18. Rossi, M.; Sansone, D.; van Soest, A.; Torricelli, C. Household preferences for socially responsible investments. J. Bank. Financ. 2019, 105, 107-120. [CrossRef]

19. Heo, W.; Rabbani, A.G.; Lee, J.M. Mediation between financial risk tolerance and equity ownership: Assessing the role of financial knowledge underconfidence. J. Financ. Serv. Mark. 2021, 26, 169-180. [CrossRef]

20. Moore, D.A.; Healy, P.J. The trouble with overconfidence. Psychol. Rev. 2008, 115, 502-517. [CrossRef] [PubMed]

21. Atlas, S.A.; Lu, J.; Micu, P.D.; Porto, N. Financial Knowledge, Confidence, Credit Use, and Financial Satisfaction. J. Financ. Couns. Plan. 2019, 30, 175-190. [CrossRef]

22. Angrisani, M.; Casanova, M. What you think you know can hurt you: Under/over confidence in financial knowledge and preparedness for retirement. J. Pension Econ. Financ. 2019. [CrossRef]

23. Porto, N.; Xiao, J.J. Financial Literacy Overconfidence and Financial Advice Seeking. J. Financ. Serv. Prof. 2016, 70, 78-88.

24. Barber, B.M.; Odean, T. Boys will be boys: Gender, overconfidence, and common stock investment. Q. J. Econ. 2001, 116, 261-292. [CrossRef]

25. Von Gaudecker, H.-M. How Does Household Portfolio Diversification Vary with Financial Literacy and Financial Advice? J. Financ. 2015, 70, 489-507. [CrossRef]

26. Kramer, M.M. Financial literacy, confidence and financial advice seeking. J. Econ. Behav. Organ. 2016, 131, 198-217. [CrossRef]

27. Di Salvatore, A.; Franceschi, F.; Neri, A.; Zanichelli, F. Measuring the Financial Literacy of the Adult Population: The Experience of Banca D'Italia; Bank of Italy Occasional Paper No. 435; Bank of Italy: Rome, Italy, 2018.

28. Pikulina, E.; Renneboog, L.; Tobler, P.N. Overconfidence and investment: An experimental approach. J. Corp. Financ. 2017, 43, 175-192. [CrossRef]

29. Xia, T.; Wang, Z.; Li, K. Financial Literacy Overconfidence and Stock Market Participation. Soc. Indic. Res. 2014, 119, 1233-1245. [CrossRef]

30. Bucher-Koenen, T.; Alessie, R.; Lusardi, A.; van Rooij, M. Fearless Woman: Financial Literacy and Stock Market Participation; ZEW Discussion Papers No. 21-015; Leibniz Centre for European Economic Research: Mannheim, Germany, 2021.

31. Aristei, D.; Gallo, M. Assessing gender gaps in financial knowledge and self-confidence: Evidence from international data. Financ. Res. Lett. 2021. [CrossRef]

32. OECD. OECD/INFE International Survey of Adult Financial Literacy Competencies, OECD, Paris. 2016. Available online: www oecd.org/finance/OECD-INFE-International-Survey-of-Adult-Financial-Literacy-Competencies.pdf (accessed on 29 September 2021). 
33. OECD. OECD/INFE 2020 International Survey of Adult Financial Literacy, OECD, Paris. 2020. Available online: https://www. oecd.org/financial/education/ oecd-infe-2020-international-survey-of-adult-financial-literacy.pdf (accessed on 29 September 2021).

34. Van Rooij, M.; Lusardi, A.; Alessie, R. Financial literacy and stock market participation. J. Financ. Econ. 2011, 101, 449-472. [CrossRef]

35. Abreu, M.; Mendes, V. Financial Literacy and Portfolio Diversification. Quant. Financ. 2010, 10, 515-528. [CrossRef]

36. Hsiao, Y.-J.; Tsai, W.-C. Financial literacy and participation in the derivatives markets. J. Bank. Financ. 2018, 88, 15-29. [CrossRef]

37. Khan, M.S.R.; Rabbani, N.; Kadoya, Y. Is Financial Literacy Associated with Investment in Financial Markets in the United States? Sustainability 2020, 12, 7370. [CrossRef]

38. Guiso, L.; Jappelli, T. Household portfolios in Italy. In Household Portfolios; Chapter 7; Guiso, L., Haliassos, M., Jappelli, T., Eds.; The MIT Press: Cambridge, MA, USA, 2020.

39. Guiso, L.; Jappelli, T. Financial Literacy and Portfolio Choice; EUI Working papers no. ECO2008/31; European University Institute: Fiesole, Italy, 2008.

40. Aristei, D.; Bacci, S.; Bartolucci, F.; Pandolfi, S. A bivariate finite mixture growth model with selection. Adv. Data Anal. Classif. 2020. [CrossRef]

41. Kurowski, Ł. Household's Overindebtedness during the COVID-19 Crisis: The Role of Debt and Financial Literacy. Risks 2021, 9, 62. [CrossRef]

42. Lagerkvist, C.J.; Edenbrandt, A.K.; Tibbelin, I.; Wahlstedt, Y. Preferences for sustainable and responsible equity funds-A choice experiment with Swedish private investors. J. Behav. Exp. Financ. 2020, 28, 100406. [CrossRef]

43. Stolper, O.A.; Walter, A. Financial literacy, financial advice, and financial behavior. J. Bus. Econ. 2017, 87, 581-643. [CrossRef]

44. Goyal, K.; Kumar, S. Financial literacy: A systematic review and bibliometric analysis. Int. J. Consum. Stud. 2021, 45, 80-105. [CrossRef]

45. Bannier, C.E.; Neubert, M. Gender differences in financial risk taking: The role of financial literacy and risk tolerance. Econ. Lett. 2016, 145, 130-135. [CrossRef]

46. Lusardi, A.; Mitchell, O.S. The economic importance of financial literacy: Theory and evidence. J. Econ. Lit. 2014, 52, 5-44. [CrossRef]

47. Hastings, J.; Mitchell, O.S. How financial literacy and impatience shape retirement wealth and investment behaviors. J. Pension Econ. Financ. 2020, 19, 1-20. [CrossRef]

48. Bucher-Koenen, T.; Lusardi, A. Financial literacy and retirement planning in Germany. J. Pension Econ. Financ. 2011, 10, 565-584. [CrossRef]

49. Disney, R.; Gathergood, J.; Weber, J. Credit counseling: A substitute for consumer financial literacy? J. Pension Econ. Financ. 2015, 14, 466-491. [CrossRef]

50. Fort, M.; Manaresi, F.; Trucchi, S. Adult financial literacy and households' financial assets: The role of bank information policies. Econ. Policy 2016, 31, 743-782. [CrossRef]

51. Alessie, R.; van Rooij, M.; Lusardi, A. Financial literacy and retirement preparation in the Netherlands. J. Pension Econ. Financ. 2011, 10, 527-545. [CrossRef]

52. Manski, C. Identification of endogenous social effects: The reflection problem. Rev. Econ. Stud. 1993, 60, 531-542. [CrossRef]

53. French, D.; McKillop, D.; Stewart, E. The effectiveness of smartphone apps in improving financial capability. Eur. J. Financ. 2020, 26, 302-318. [CrossRef]

54. Lewbel, A. Using heteroscedasticity to identify and estimate mismeasured and endogenous regressor models. J. Bus. Econ. Stat. 2012, 30, 67-80. [CrossRef]

55. Bucher-Koenen, T.; Alessie, R.; Lusardi, A.; van Rooij, M. How financially literate are women? An overview and new insights. J. Consum. Aff. 2017, 51, 255-283. [CrossRef]

56. Cupák, A.; Fessler, P.; Schneebaum, A.; Silgoner, M. Decomposing gender gaps in financial literacy: New international evidence. Econ. Lett. 2018, 168, 102-106. [CrossRef]

57. Swiecka, B.; Yesildag, E.; Özen Grima, S. Financial Literacy: The Case of Poland. Sustainability 2020, 12, 700. [CrossRef]

58. Kadoya, Y.; Khan, M.S.R. Financial Literacy in Japan: New Evidence Using Financial Knowledge, Behavior, and Attitude. Sustainability 2020, 12, 3683. [CrossRef]

59. Aristei, D.; Gallo, M. Does gender matter for firms' access to credit? Evidence from international data. Financ. Res. Lett. 2016, 18, 67-75. [CrossRef]

60. DeLiema, M.; Deevy, M.; Lusardi, A.; Mitchell, O.S. Financial fraud among older Americans: Evidence and implications. J. Gerontol. Ser. B 2020, 75, 861-868. [CrossRef]

61. Deevy, M.; Lucich, S.; Beals, M. Scams, Schemes and Swindles-A Review of Consumer Financial Fraud Research; Working paper; Financial Fraud Research Center: Stanford Center on Longevity: Stanford, CA, USA, 2012.

62. French, D.; McKillop, D. Financial Literacy and Over-Indebtedness in Low-Income Households. Int. Rev. Financ. Anal. 2016, 48, 1-11. [CrossRef]

63. Meyll, T.; Pauls, T. The gender gap in over-indebtedness. Financ. Res. Lett. 2019, 31, 398-404. [CrossRef]

64. Gathergood, J. Self-control, financial literacy and consumer over-indebtedness. J. Econ. Psychol. 2012, 33, 590-602. [CrossRef] 